\title{
The "minute diving beetles" of southern Australia - taxonomic revision of Gibbidessus Watts, 1978, with description of six new species (Coleoptera, Dytiscidae, Bidessini)
}

\author{
Lars Hendrich', Chris H.S. Watts², Michael Balke ${ }^{3}$
}

I SNSB - Zoologische Staatssammlung München, Münchhausenstraße 21, D - 81247 München, Germany 2 South Australian Museum, North Terrace, Adelaide, South Australia 5000, Australia 3 SNSB - Zoologische Staatssammlung München, Münchhausenstraße 21, D-81247 München, Germany

Corresponding author: Lars Hendrich (hendrich@snsb.de)

Academic editor: M. Michat | Received 15 June 2020 | Accepted 8 September 2020 | Published 12 October 2020

http://zoobank.org/785EDF22-5A32-4217-8C9B-6433E0AD199F

Citation: Hendrich L, Watts CHS, Balke M (2020) The "minute diving beetles" of southern Australia - taxonomic revision of Gibbidessus Watts, 1978, with description of six new species (Coleoptera, Dytiscidae, Bidessini). ZooKeys 975: 11-49. https://doi.org/10.3897/zookeys.975.55456

\begin{abstract}
Morphology and mitochondrial DNA sequence data are used to reassess the taxonomy of Australian diving beetles previously assigned to the genera Uvarus Guignot, 1939 and Gibbidessus Watts, 1978. Gibbidessus was described as a monotypic genus for Gibbidessus chipi Watts, 1978. The genus is significantly extended here. Based on molecular systematic evidence, Uvarus pictipes (Lea, 1899) is transferred to Gibbidessus. Gibbidessus chipi and Gibbidessus pictipes comb. nov. are redescribed, and six new species are described: Gibbiddessus atomus sp. nov. (SW Australia, Northcliffe area) [the smallest epigean diving beetle in Australia], G. davidi sp. nov. (SW Australia), G. drikdrikensis sp. nov. (Victoria), G. kangarooensis sp. nov. (SA Kangaroo Island), G. pederzanii sp. nov. (SW Australia, Nannup area), and G. rottnestensis sp. nov. (SW Australia). Species are delineated using characters such as male genital structure and beetle size, shape and colour pattern. Mitochondrial Cox1 data for 27 individuals, representing five species, were generated, and revealed clusters congruent with the morphological evidence. Gibbidessus occur in southern Australia, with the centre of diversification in the isolated peat- and wetlands of SW Australia. All species occur in very shallow water of seasonal, exposed or half-shaded wetlands and flooded meadows.
\end{abstract}

\section{Keywords}

Key, mitochondrial DNA, new species, smallest epigean Australian Dytiscidae species, southern Australia, temporary wetlands, peatlands

Copyright Lars Hendrich et al. This is an open access article distributed under the terms of the Creative Commons Attribution License (CC BY 4.0), which permits unrestricted use, distribution, and reproduction in any medium, provided the original author and source are credited. 


\section{Introduction}

With 726 described species the Bidessini belong to the most diverse tribes of the Dytiscidae (Nilsson and Hájek 2020). Bidessini genera have to date been justified mainly based on a diagnostic combination of structural features (Biström 1988; Miller and Short 2015), rather than apomorphies. This had to lead to the recognition of genera that render others paraphyletic (Balke and Ribera 2004). Some of these features, such as presence / absence of an elytral plica or occipital line, have been shown to vary within clades of closely related species (Balke et al. 2015). In this context, the use of phylogenetic reconstructions based on DNA sequence data offers a source of information that helps to delineate monophyletic entities (Hendrich and Balke 2009; Balke et al. 2013). In Australia, the situation is currently rather stable. Most Australian genera have been revised or will be revised in the near future (Balke and Ribera 2004; Watts 1978; Watts and Humphreys 2001, 2003, 2004, 2006, 2009; Watts and Leys 2005; Hendrich and Wang 2006; Hendrich and Balke 2009).

In this work we focus on the genus Gibbidessus Watts, 1978. These are widespread diving beetles of south-western and south-eastern Australia, but rarely collected, supposedly due to their small size. In fact, some of the species belong to the smallest epigean Australian Dytiscidae. We use molecular systematic evidence to redefine the genus and taxonomically treat all species now assigned to Gibbidessus, two known ones and six new species. We provide mitochondrial 3' $\operatorname{cox} 1$ sequence data for five species.

\section{Materials and methods}

Material: This study is based on the examination of 767 specimens. Types of the two previously known species were examined. Most of the specimens were collected in the past 25 years by LH and CHS Watts. Additional material was collected by Melita Pennifold of the Department of Parks and Wildlife in many parts of south-western Australia, and by Australian Water Quality in South Australia. Furthermore, the authors have studied all available specimens stored in relevant Australian museums.

Descriptions: Beetles were studied with a Leica M205C dissecting microscope at 10-100x. Male genitalia were studied and figured in dry condition. The terminology to denote the orientation of the genitalia follows Miller \& Nilsson (2003). Abbreviations used in the text are: TL (total length), TL-H (total length without head), and MW (maximum width). Label data of type material are cited between quotation marks.

Photos and illustrations: Images were taken with a Canon EOS 5DS camera fitted with a Mitutoyo 10× (habitus) or 20× (genital structures) ELWD Plan Apo objective attached to a Carl Zeiss Jena Sonnar 3.5/135 MC as focus lens. Illumination was with two to three LED segments SN-1 from Stonemaster (https://www.stonemaster-onlineshop. de). Image stacks were generated using the Stackmaster macro rail (Stonemaster), and images were then assembled with the computer software Helicon Focus 4.77TM. 
Table I. GenBank accession numbers for Gibbidessus cox1 3'end mtDNA sequences.

\begin{tabular}{|c|c|c|}
\hline Species & Voucher & COI-3, accession \\
\hline \multirow[t]{3}{*}{ Gibbidessus atomus sp. nov. } & MB 1729 & FR732713 \\
\hline & MB 2780 & FR733522 \\
\hline & MB 2781 & FR733523 \\
\hline Gibbidessus chipi & N/A & AF484132 \\
\hline \multirow[t]{7}{*}{ Gibbidessus davidi sp. nov. } & MB 1730 & FR732714 \\
\hline & MB 2782 & FR733524 \\
\hline & MB 2783 & FR733525 \\
\hline & MB 7243 & MT551887 \\
\hline & MB 7244 & MT551888 \\
\hline & MB 7245 & MT551889 \\
\hline & MB 7246 & MT551890 \\
\hline \multirow[t]{12}{*}{ Gibbidessus pictipes } & MB 1695 & FR732684 \\
\hline & MB 2104 & FR733521 \\
\hline & MB 7250 & MT551896 \\
\hline & MB 7252 & MT551895 \\
\hline & MB 7253 & MT551894 \\
\hline & MB 7254 & MT551893 \\
\hline & MB 7255 & MT551892 \\
\hline & MB 7257 & MT551891 \\
\hline & MB 7259 & MT551900 \\
\hline & MB 7260 & MT551899 \\
\hline & MB 7261 & MT551898 \\
\hline & MB 7262 & MT551897 \\
\hline \multirow[t]{4}{*}{ Gibbidessus rottnestensis sp. nov. } & MB 3921 & MT551904 \\
\hline & MB 7247 & MT551901 \\
\hline & MB 7248 & MT551902 \\
\hline & MB 7249 & MT551903 \\
\hline
\end{tabular}

Coordinates are given in decimal notation unless cited verbatim from labels. Besides various Australian road maps, we also used Google Earth (http://earth.google.com) to locate several localities, and their coordinates are given in Degrees, Minutes (DDD ${ }^{\circ}$ MM'). Our maps are based on "MICROSOFT ENCARTA World-Atlas 2000".

DNA sequencing and data analysis: Our laboratory protocol has been explained in Hendrich et al. (2010). We used the 3' end of the cox 1 gene, widely used in diving beetle research. Each of our 27 individual vouchers bears a green cardboard label that indicates the DNA extraction number of M. Balke (e.g., "DNA M. Balke 7247”). This number links the DNA sample to the dry-mounted voucher specimen, deposited in Zoologische Staatssammlung München (ZSM). We used a simple approach to calculate a neighborjoining tree ( $p$-distances) in Geneious (11.0.4.) software (Fig. 26), and subsequent visual inspection of the tree to learn whether there was any hidden diversity or haplotype sharing.

GenBank accession numbers are provided in Table 1.

\section{Codens}
ANIC Australian National Insect Collection, Canberra, Australia
CFP
Collection Fernando Pederzani, Ravenna, Italy
CGC
Collection Gilbert L. Challet, Florida, United States 
CLH Collection Lars Hendrich, Berlin, Germany; property of the NMW

DPAW Department of Parks \& Wildlife, Kensington, Australia

NMW Naturhistorisches Museum Wien, Vienna, Austria

SAMA South Australian Museum, Adelaide, South Australia, Australia

WAM Western Australian Museum, Perth, Western Australia, Australia

ZSM Zoologische Staatssammlung München, Munich, Germany

\section{Collecting procedures}

Most of the specimens were collected in the flat transition zones between land and water ( 1 to $5 \mathrm{~cm}$ depth) of seasonal, mainly open swamps, smaller pools, puddles and flooded meadows, using various kinds of aquatic dip nets and plastic strainers with very fine meshes. Mesh diameters varied from 0.1 to $0.5 \mathrm{~mm}$. Most specimens were collected directly from the plastic strainers with forceps and/or an aspirator. According to our knowledge and the label data studied, none of the eight species has ever been obtained via light traps.

\section{Taxonomy}

\section{Checklist of Gibbidessus species}

NSW = New South Wales; SA = South Australia; TAS, = Tasmania; VIC = Victoria; $\mathrm{WA}=$ Western Australia.

G. atomus sp. nov.

G. chipi Watts, 1978

G. davidi sp. nov.

G. drikdrikensis sp. nov.

$G$. kangarooensis sp. nov.

G. pederzanii sp. nov.

G. pictipes (Lea, 1899) comb. nov.

G. rottnestensis sp. nov. south-western WA SA, VIC, TAS, NSW south-western WA south-western VIC SA (Kangaroo Island) south-western WA south-western WA south-western WA

\section{Genus Gibbidessus Watts, 1978}

Gibbidessus Watts, 1978: 29; gender masculine; type species: Gibbidessus chipi Watts, 1978: 52 by original designation; Biström (1988: 19); Nilsson \& Hájek (2020: 108).

Type species. Gibbidessus chipi Watts, 1978.

Diagnosis. Very small diving beetles $(1.15-1.9 \mathrm{~mm})$. The smallest epigean dytiscids in Australia can be found in this genus. Body oblong-oval or elongate and fairly 
compactly built. Head with or without cervical line; frontally not bordered. Palpi rather slender, apically very finely bifid, in one species broad. Pronotum with a pair of basal striae. Elytron with a basal stria but without sutural striae. Punctation of elytra does not form rows. Epipleura lack a basal cavity posteriorly limited by a transverse carina. Prosternal process rather elongate, narrow, laterally distinctly marginated and with ventral surface not medially excavated. Prosternal process reaches metaventrite, which is not distinctly depressed posterior to mesocoxae. Metacoxal lines comparatively short, only slightly longer than distance between them posteriorly. Very fine punctures on either side of midline of metaventrite, not forming distinct rows. Metatrochanters and metafemora not distinctly modified (Biström 1988; Hendrich et al. 2019). Parameres symmetric. Larvae unknown.

Gibbidessus was described as a monotypic genus to accommodate G. chipi Watts, 1978. A molecular phylogenetic investigation covering all Australian Bidessini genera (Hendrich et al. 2010) recovered G. chipi, the single Uvarus species reported from Australia, Uvarus pictipes (Lea, 1899), as well as three undescribed species in one clade (Fig. 26). We refer to this clade as genus Gibbidessus. Subsequently, we assembled a multigene dataset of global Hydroporinae (Balke, work in progress), where we again recovered Gibbidessus species as well as Uvarus pictipes in one clade. The non-Australian Uvarus included in that preliminary study did form a separate, not closely related clade. Consequently, Uvarus pictipes is transferred to Gibbidessus here.

\section{Gibbidessus atomus sp. nov.}

http://zoobank.org/713DD48F-BA41-4581-A05F-DEECAED51519

Figs 1, 14, 23, 27

Type locality. Western Australia, Windy Harbour Road, $11 \mathrm{~km}$ south of Northcliffe, small pool in sedge swamp [34\% $48^{\prime} 51 \mathrm{~S}, 116^{\circ} 4^{\prime} 8 \mathrm{E}$ ].

Type material. Holotype, male: "Australia: SW WA, D'Entrecasteaux NP, $11 \mathrm{~km}$ S, Northcliffe, 77m, 4.I.2007, 34.44.048S, 116.05.354E [3444'0S, $116^{\circ} 5^{\prime} 13 \mathrm{E}$ ], L. \& E. Hendrich (WA 162)", "Holotype Gibbidessus atomus Hendrich, Watts \& Balke des. 2020" [red printed label] (WAM). Paratypes (20 exs.). 7 specimens with same data as holotype, three specimens with "DNA M. Balke 1729", "DNA M. Balke 2780", "DNA M. Balke 2781" [green printed labels]; 13 exs., "AUSTRALIA/WA: D'Entrecasteaux N.P., $11 \mathrm{~km}$ south of Northcliffe, Windy Harbour Road, $50 \mathrm{~m}, 3.1 .2000,34^{\circ} 42^{\prime} \mathrm{S}$,

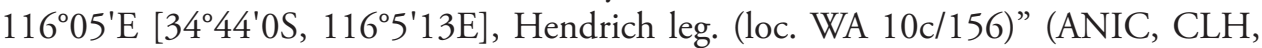
SAMA, ZSM). All paratypes with red printed paratype labels.

Additional material. 1 ex., "Australia, WA, RVDLE03 Riverdale Wetland [32 59'22S, $115^{\circ} 47^{\prime} 7 \mathrm{E}$ ], 23/09/2008, South West Catchment Council Mon." (DPAW).

Diagnosis. Very small species, externally characterised by widely rounded body, with less pronounced habitus disruption between pronotum and elytron, shiny nonmicroreticulate dorsal surface and vague ferruginous markings on elytra. Dorsoventrally rather domed. Cervical line present (Fig. 1). 


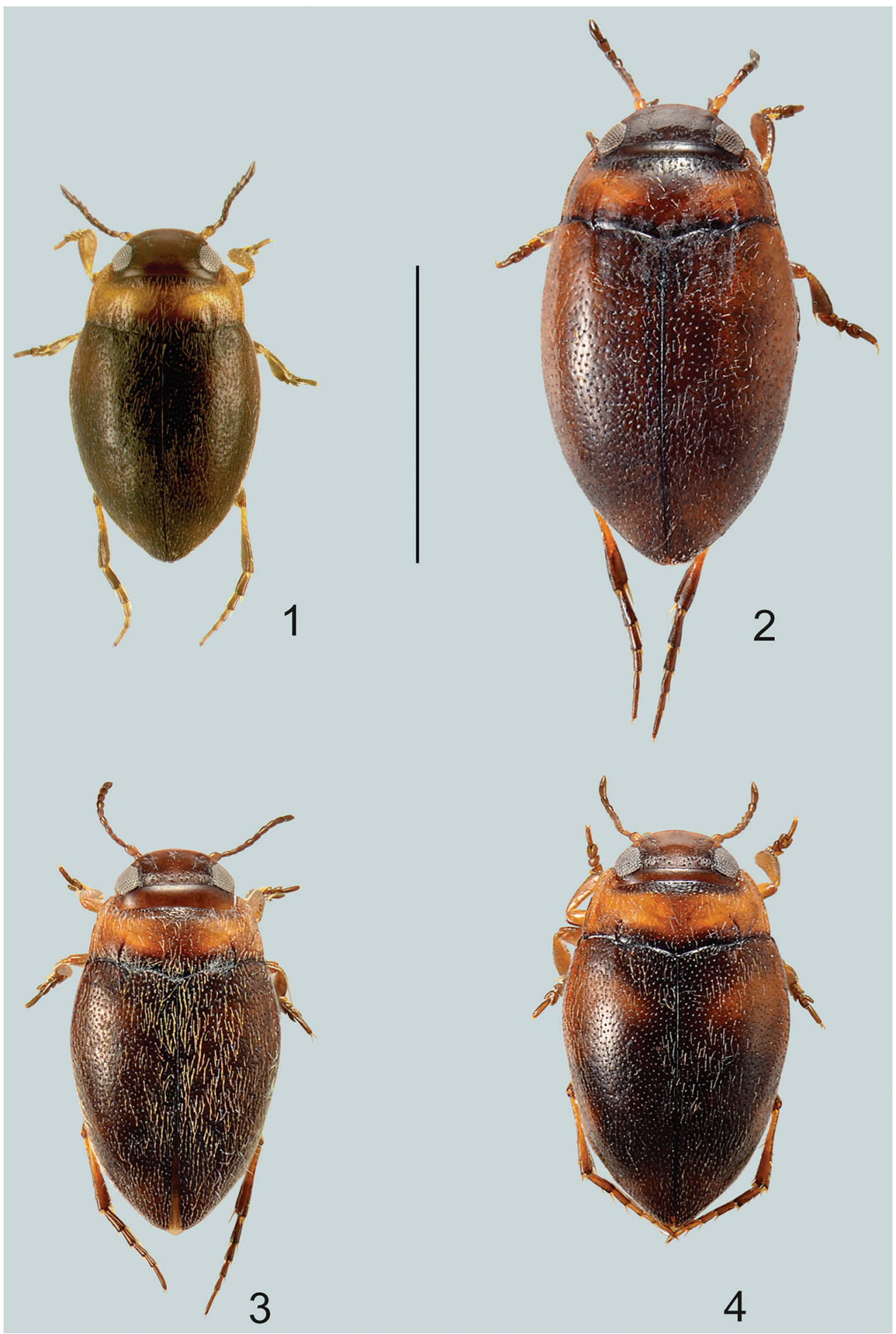

Figures I-4. Habitus of I Gibbidessus atomus sp. nov. 2 G. chipi, $\mathbf{3}$ G. davidi, male 4 G. davidi female. Scale bar: $1.0 \mathrm{~mm}$. 
Measurements. Holotype: $\mathrm{TL}=1.15 \mathrm{~mm}, \mathrm{TL}-\mathrm{H}=1.05 \mathrm{~mm}, \mathrm{MW}=0.6 \mathrm{~mm}$. Paratypes: $\mathrm{TL}=1.15-1.30 \mathrm{~mm}, \mathrm{TL}-\mathrm{H}=1.0-1.05 \mathrm{~mm}, \mathrm{MW}=0.6-0.65 \mathrm{~mm}$.

Head: Dark brown, around eyes almost black. Cervical line present. Strongly and coarsely punctate, rather shiny, microsculpture almost absent. Punctures weakly distributed anteriorly, strong posteriorly between eyes. Antennae relatively short, stout. Antennomeres ferruginous, darkened anteriorly.

Pronotum: Ferruginous, anterior and posterior margins darker. Disc of pronotum somewhat darkened, broadest at posterior corners. Punctation very weakly, almost evenly distributed, shiny, microsculpture absent. Sides of pronotum margined and almost evenly rounded. Angle between pronotum and elytra less pronounced, basal pronotal plicae present. Striae moderately defined, on almost $1 / 2$ length of pronotum, moderately incurved.

Elytra: Dark brown with vague basal area ferruginous (Fig. 1). Coarsely and densely punctate, shiny, microsculpture absent. Striae weakly impressed, slightly straighter but shorter than basal pronotal striae.

Ventral side: Ferruginous. Prothorax and apex of abdomen paler than other parts. Metacoxae and metaventrite covered with numerous larger punctures, surface shiny, without microreticulation. Abdominal ventrites with dense and finer punctures, shiny, microreticulation absent. Metacoxal lines almost straight, anteriorly slightly divergent. Epipleuron ferruginous, coarsely punctate, shiny, lacking microsculpture. Legs ferruginous with meta-/mesotibiae and meta-/mesotarsi set in black.

Male. Dorsal surface with coarse punctures but otherwise with shiny surface (Fig. 1). Median lobe of aedeagus as in Fig. 14A, B. Shape of median lobe fairly uniform, bent evenly, apex straight and pointed. Paramere, as in Limbodessus Guignot, 1939, with hook or bent finger-like apical part with tiny setae on tip (Fig. 14C).

Affinities. This species is similar to $G$. davidi sp. nov. but readily separated by its smaller size, the different colour pattern and the form of the median lobe and parameres (Figs 14, 16).

Etymology. From Latin atomus (smallest particle), as it is the smallest epigean diving beetle in Australia described so far.

Distribution. South-western Australia. Known only from the type locality in the D'Entrecasteaux National Park, south of Northcliffe and the Riverdale Wetland [32 $\left.59^{\prime} 22 \mathrm{~S}, 115^{\circ} 47^{\prime} 7 \mathrm{E}\right]$ (Fig. 23).

Habitat. Most specimens were obtained from an exposed, shallow and small roundish puddle without any vegetation, except some algae (Fig. 27B). The remaining specimens were collected in a half-shaded pool in a Melaleuca blackwater swamp (Fig. 27A), with few clumps of Juncus spp. and extensive beds of macrophytes; depth up to $20 \mathrm{~cm}$; bottom of sedge-filled peat ( $\mathrm{pH} 5.5$ ), twigs and rotten leaves. The heathlands south of Northcliffe are seasonally flooded, with some permanent water bodies in the summer. At Northcliffe the species is syntopic with $G$. davidi sp. nov. (Hendrich 2001a), at the Riverdale Wetland it was collected with $G$. davidi sp. nov. and $G$. rottnestensis sp. nov.

Apart from the Gibbidessus, the water beetle coenosis at Northcliffe included the following species: Dytiscidae: Limbodessus inornatus (Sharp, 1882), 
Antiporus hollingsworthi Watts, 1997, A. mcraeae Watts \& Pinder, 2000, Brancuporus gottwaldi (Hendrich, 2001), Sternopriscus minimus Lea, 1899, S. eikei Hendrich \& Watts, 2007, Exocelina ater (Sharp, 1882); Hydrophilidae: Enochrus eyrensis (Blackburn, 1895), Limnoxenus zealandicus (Broun, 1880), Paracymus pygmaeus (Macleay, 1871).

\section{Gibbidessus chipi Watts, 1978}

Figs 2, 15, 22

Gibbidessus chipi Watts, 1978: 33 (original description); Watts (1985: 24, checklist); Lawrence et al. (1987: 335, catalogue); Biström (1988: 19, systematics); Watts (2002: 31, 44, identification key, checklist); Davies et al. (2003: 24, 27, faunistics); Nilsson \& Hájek (2020: 108, catalogue).

Type locality. Australia, New South Wales, Collector, old farm dam [3454' 40 S, $149^{\circ} 26$ '24E].

Type material. Holotype, male [with one paratype on the same plate]: "Collector NSW Febr 1961 C.W.", "Holotype" [red printed label], "ANIC Database No. 25 015140" [printed label], "Holotype Gibbidessus chipi Det. C. Watts 1976 [handwritten label by Chris Watts] (ANIC). Paratypes (10 exs.). 2 males, 4 females: "Collector NSW 2/61" [handwritten label by Chris Watts], "Paratype Gibbidessus chipi Det C. Watts 1976" [white, printed and handwritten label], "ANIC Database No 2515141" (ANIC); 2 males: "Collector NSW 2/61" [handwritten label by Chris Watts], "Paratype Gibbidessus chipi Det C. Watts 1976" [white, printed and handwritten label], "SAMA Database No 25-003994" (SAMA); 1 male, 1 female: "Dartmoor Victoria Jan 59. CW" [handwritten label], "Paratype Gibbidessus chipi Det C. Watts 1976" [white, printed and handwritten label], "SAMA Database No 25-003398" (SAMA).

Additional material studied (17 exs.): South Australia. 2 exs., "1 km S, Nangwarry 5.X.2000, C. Watts leg.", "SAMA Database No 25-004002", one specimen "DNA M. Balke 2109 [green printed label] (SAMA, ZSM); 3 exs., "Fleurieu Peninsula, Myponga, A.H. Elston leg.", "SAMA Database No 25-00399" (SAMA); 1 ex., "Mt. Crawford State Forest, Watts Gully, 3.X.1998, C. Watts leg.", "SAMA Database No 25-003996" (SAMA). Victoria: 1 ex., "5.3 km S, Drik Drik, 14. VIII.2004, C. Watts leg.", "DNA Voucher d" (SAMA); 6 exs., "18 km W Casterton, 25.IX.1998, C. Watts leg.", "SAMA Database No 25-004003” (SAMA); 3 exs., "18 km W Casterton, 25.IX.1998, C. Watts leg." (CLH); 1 ex., " 22 km W Casterton, 23.IX.1999, C. Watts leg.", "photographed" [yellow label], "SAMA Database No 25-004004" (SAMA).

Diagnosis. Medium-sized species which externally is characterised by a widely rounded body, shiny non-microreticulate dorsal surface, vague testaceous markings on elytra, and without habitus disruption between pronotum and elytron. Dorsoventrally rather domed. Cervical line present (Fig. 2).

Measurements. $\mathrm{TL}=1.5-1.55 \mathrm{~mm}, \mathrm{TL}-\mathrm{H}=1.4-1.45 \mathrm{~mm}, \mathrm{MW}=0.86-0.98 \mathrm{~mm}$. 
Head: Dark brown, around eyes almost black. Cervical line present. Strongly and coarsely punctate, rather shiny, microsculpture almost absent. Punctures weakly anteriorly and strongly posteriorly between eyes. Antennae relatively short, stout. Antennomeres 1-2 ferruginous, 3-11 darkened anteriorly.

Pronotum: Ferruginous, anterior and posterior margins darker. Disc of pronotum somewhat darkened, broadest at posterior corners. Punctation very weakly punctate almost evenly distributed, shiny and microsculpture absent. Sides of pronotum margined and almost evenly rounded. Angle between pronotum and elytra not pronounced, basal pronotal plicae present. Striae well defined, almost $1 / 2$ length of pronotum, strongly incurved.

Elytra: Ferruginous, with vague areas darkened (Fig. 2). Coarsely and densely punctate, shiny, microsculpture absent. Striae strongly impressed, same length as basal pronotal striae but slightly straighter.

Ventral side: Ferruginous. Prothorax and abdomen paler than other parts. Metacoxae and metaventrite covered with numerous larger punctures, surface shiny, without microreticulation. Abdominal ventrites with dense and fine punctures, shiny, microreticulation absent. Metacoxal lines almost straight, anteriorly slightly divergent. Epipleuron testaceous, with few coarse punctures, shiny, lacking microsculpture. Legs ferruginous with meta-/mesotibia and meta-/mesotarsi set in black.

Male. Dorsal surface with coarse punctures but otherwise with shiny surface Fig. 2. Median lobe of aedeagus as in Fig. 15A, B. Shape of median lobe fairly uniform, apex in lateral view straight and pointed, in ventral view very broad and rounded at apex. Parameres bi-segmented and elongated with few setae at apex (Fig. 15C).

Affinities. This species is similar to $G$. drikdrikensis sp. nov. but readily separated by its smaller size, and the form of the median lobe (Figs 15, 17).

Distribution. South-eastern Australia, from the Lofty Ranges near Adelaide and north-eastern Tasmania to Canberra (Watts 1978). Also recorded from King Island, Bertie Lagoon [39 $42^{\prime} 36 \mathrm{~S}, 144^{\circ} 4^{\prime} 24 \mathrm{E}$ ] (Davies et al. 2003), northwest of Tasmania (Fig. 22).

Habitat. The type specimens were collected in an old farm dam and its flood zone, overgrown by rich vegetation. In Victoria and South Australia most of the specimens were collected in small shallow pools and seasonal wetlands. A single specimen from South Australia (Mount Crawford State Forest, Watts Gully) has been found in a shallow, slow flowing temporary forest creek. At Dri Drik, in Victoria, the species is syntopic with $G$. drikdrikensis sp. nov.

\section{Gibbidessus davidi sp. nov.}

http://zoobank.org/4D235E7C-F517-4C1D-A3C7-0C87BDA34515

Figs $3,4,12,16,23,27,28$

Type locality. Western Australia, Perth, suburb Success, Beeliar Regional Park, shallow peaty puddle $\left[32^{\circ} 8^{\prime} 4 S, 115^{\circ} 50^{\prime} 22 \mathrm{E}\right]$. 
Type material. Holotype, male: "Australia, WA, Perth, Success, Beeliar RP, shallow peaty puddle $32^{\circ} 8^{\prime} 4.97^{\prime \prime S}, 115^{\circ} 50^{\prime} 22.78^{\prime \prime}$ 21.-31.10.2015 L. Hendrich (WA 1/15)", "Holotype Gibbidessus davidi Hendrich, Watts \& Balke des. 2020" (WAM) [red printed label]. Paratypes (370 exs.). 354 specimens with same data as holotype (ANIC, CGC, CLH, SAMA, WAM, ZSM); 4 exs, "Australia: SW WA, D'Entrecasteaux NP, $11 \mathrm{~km} \mathrm{S,} \mathrm{Northcliffe,} \mathrm{77m,} \mathrm{4.I.2007,} \mathrm{34.44.048S,} \mathrm{116.05.354E}$ [344ㄴ' $0 S$, $\left.116^{\circ} 5^{\prime} 13 \mathrm{E}\right]$, L. \& E. Hendrich (WA 162)" (ZSM); 10 exs., "Australia, WA, Albany Hwy, Muir Lakes Nature Reserve, SW part of Byenup Lagoon, 4.\& 5.1.2000, 34³0'4S, 11644'19E, Hendrich leg. (loc. WA 11/157)" (CLH, ZSM); 1 ex., "Aus-

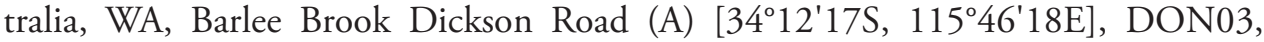
21/10/2005, South West Forest Monitoring" (DPAW); 1 ex., "Australia, WA, Fish

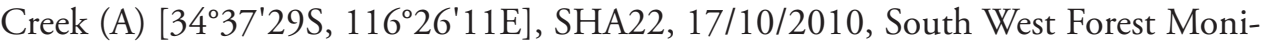
toring" (DPAW); 4 exs., "Australia, WA, RVDLE03 Riverdale Wetland [32 $59^{\circ} 23$ S, $\left.115^{\circ} 47^{\prime} 23 E\right], 23 / 09 / 2008$, South West Catchment Council Mon.” (DPAW). All paratypes with red printed paratype labels.

Diagnosis. Small species which externally is characterised by a wide rounded body, shiny non-microreticulate dorsal surface, vague testaceous markings on elytra, and without habitus disruption between pronotum and elytron. Dorsoventrally rather domed. Cervical line present (Fig. 3).

Measurements. Holotype: $\mathrm{TL}=1.45 \mathrm{~mm}, \mathrm{TL}-\mathrm{H}=1.35 \mathrm{~mm}, \mathrm{MW}=0.83 \mathrm{~mm}$. Paratypes: $\mathrm{TL}=1.35-1.5 \mathrm{~mm}, \mathrm{TL}-\mathrm{H}=1.15-1.4 \mathrm{~mm}, \mathrm{MW}=0.8-0.9 \mathrm{~mm}$.

Head: Ferruginous, around eyes almost black. Cervical line present (Fig. 12A). Strongly and coarsely punctate, rather shiny, microreticulation present. Punctures weak anteriorly and strongly posteriorly between eyes. Antennae relatively short, stout. Antennomeres 1-8 ferruginous, 9-11 darkened anteriorly.

Pronotum: Ferruginous, anterior and posterior margins darker. Disc of pronotum somewhat darkened, broadest at posterior corners. Punctation of pronotum very weak, almost evenly distributed, shiny and microsculpture absent. Sides of pronotum margined and almost evenly rounded. Angle between pronotum and elytra less pronounced, basal pronotal plicae present. Striae moderately defined, almost $1 / 2$ length of pronotum, strongly incurved.

Elytra: Dark brown with vague basolateral area ferruginous (Fig. 3). Coarsely and densely punctate, shiny, microsculpture absent. Striae deeply impressed, straight but shorter than basal pronotal striae.

Ventral side: Ferruginous. Prothorax and abdomen paler than other parts. Metacoxae and metaventrite covered with larger punctures, surface shiny, without microreticulation. Abdominal ventrites with dense and finer punctures, shiny, microreticulation absent. Metacoxal lines almost straight, anteriorly not divergent. Epipleuron ferruginous, with few coarse punctures, shiny, lacking microsculpture. Legs ferruginous with meta-/mesotibia and meta-/mesotarsi set in black.

Male. Smaller and more elongate than female (Fig. 4). Median lobe of aedeagus as in Fig. 16A, B. Shape of median lobe in lateral view, straight and fairly uniform, 
in ventral view broad, with a thorn on each side, and rounded at apex. Parameres bisegmented and elongated with few setae at apex (Fig. 16C, D).

Affinities. This species is similar to $G$. atomus sp. nov. but readily separated by its larger size, the different colour pattern and the form of the median lobe and parameres (Figs 14, 16). From $G$. pederzanii sp. nov. it can be distinguished by the less roundish body and the form of the median lobe and parameres (Figs 16, 19).

Etymology. The beetle is named after the son of the first author, David Hendrich. The specific epithet is a substantive in the genitive case.

Distribution. South-western Australia. From Perth in the north to D'Entrecasteaux National Park in the south (Fig. 23).

Habitat. In the Northcliffe area most specimens were obtained from an exposed, shallow and small roundish puddle, without any vegetation, except some algae. The other specimens were collected in a half-shaded pool in a Melaleuca blackwater swamp, with few clumps of Juncus spp. and extensive beds of macrophytes; depth up to $20 \mathrm{~cm}$; bottom consisted of sedge-filled peat ( $\mathrm{pH}$ 5.5), twigs and rotten leaves (Figs 27, 28). The whole area south of Northcliffe is seasonally flooded with some permanent central water bodies in summer. In the D'Entrecasteaux NP the species is syntopic with $G$. atomus sp. nov., and around Perth in the Beeliar Regional Park with $G$. rottnestensis sp. nov. At the Riverdale Wetland Reserve $G$. davidi sp. nov. was syntopic with $G$. atomus sp. nov. and $G$. rottnestensis sp. nov.

Apart from the Gibbidessus, the water beetle coenosis at Northcliffe included the following species: Dytiscidae: Limbodessus inornatus, Antiporus hollingsworthi, A. mcraeae, Brancuporus gottwaldi, Sternopriscus minimus, S. eikei, Exocelina ater; Hydrophilidae: Enochrus eyrensis, Limnoxenus zealandicus, Paracymus pygmaeus (see Hendrich 2001a). In the Beeliar Park the two Gibbidessus species share their habitat with Limbodessus inornatus, Paroster insculptilis (Clark, 1862), Exocelina ater, Rhantus suturalis (Macleay, 1825) and Rhantus simulans Régimbart, 1908.

\section{Gibbidessus drikdrikensis sp. nov.}

http://zoobank.org/281FB8F4-C366-40CA-9358-6BF75CBCE8DD

Figs 5, 17, 22

Type locality. Australia, Victoria, Drik Drik, old farm dam [3759'27S, $141^{\circ} 17^{\prime} 18 \mathrm{E}$ ].

Type material. Holotype: Male, "1 km S, Drik Drik Vic. 24/9/98 C. Watts", "Photographed", "SAMA Database No 25-004000", "Holotype Gibbidessus drikdrikensis sp.nov. Hendrich, Watts \& Balke des. 2020" [red printed label] (SAMA). Paratypes (6 exs.): 6 specimens with same data as holotype. Two specimens with "DNA voucher b" and "DNA voucher c" and one with a yellow prointed label "photographed" (CLH, SAMA). All paratypes are provided with printed red paratype labels.

Diagnosis. Medium-sized species which externally is characterised by a wide rounded body, shiny non-microreticulate dorsal surface, vague testaceous markings 


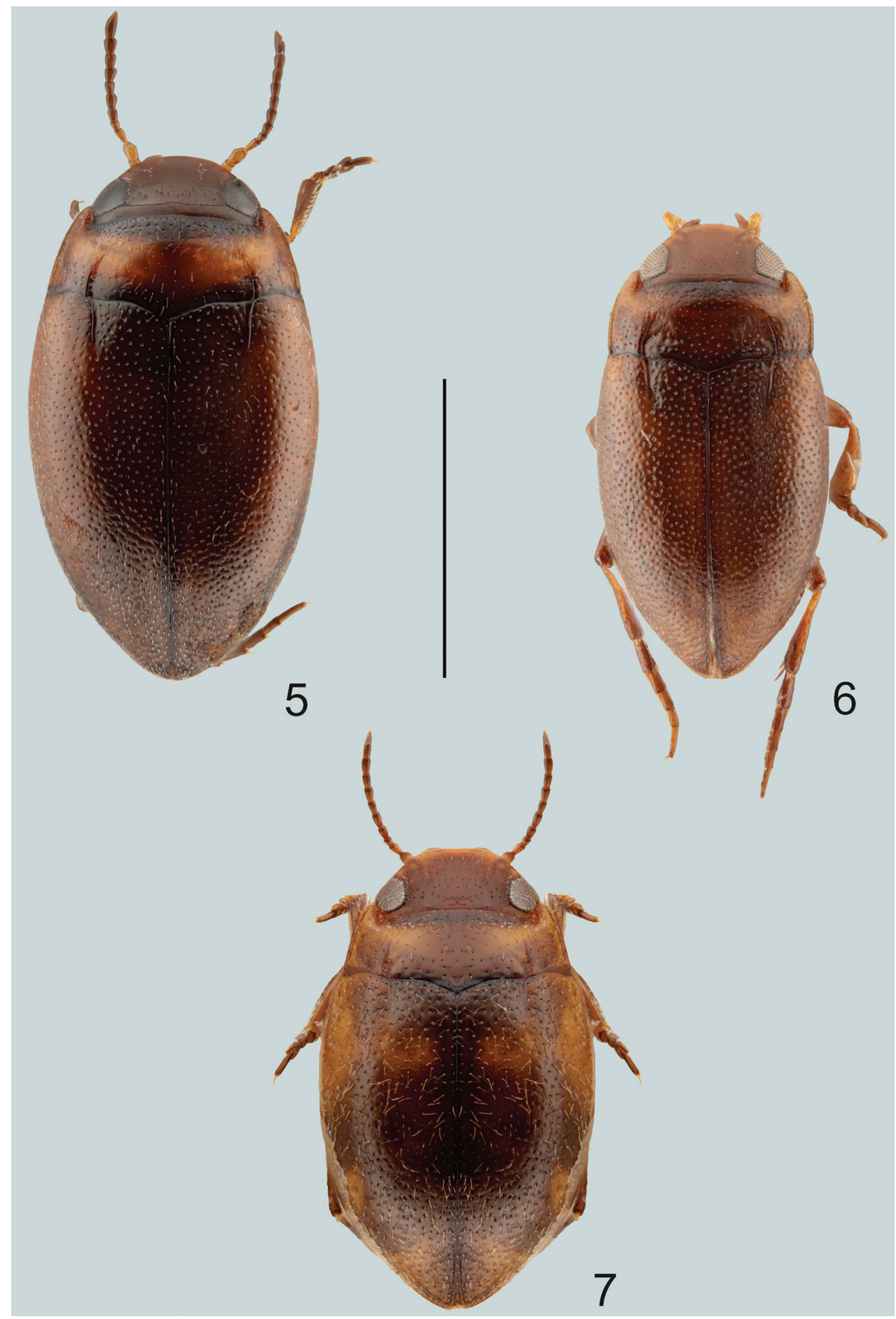

Figures 5-7. Habitus of $\mathbf{5}$ Gibbidessus drikdrikensis sp. nov. 6 G. kangarooensis sp. nov. 7 G. pederzanii sp. nov. Scale bar: $1.0 \mathrm{~mm}$. 
on elytra, and without slight habitus disruption between pronotum and elytron. Dorsoventrally rather domed. Cervical line present (Fig. 5).

Measurements. Holotype: $\mathrm{TL}=1.7 \mathrm{~mm}, \mathrm{TL}-\mathrm{H}=1.5 \mathrm{~mm}, \mathrm{MW}=0.98 \mathrm{~mm}$. Paratypes: $\mathrm{TL}=1.6-1.7 \mathrm{~mm}, \mathrm{TL}-\mathrm{H}=1.4-1.5 \mathrm{~mm}, \mathrm{MW}=0.86-0.98 \mathrm{~mm}$.

Head: Dark brown, around eyes almost black. Cervical line present. Strongly and coarsely punctate, rather shiny, microsculpture almost absent. Punctures weakly anteriorly and strongly posteriorly between eyes. Antennae relatively short, stout. Antennomeres 1 and 2 ferruginous, 3-11 darkened anteriorly.

Pronotum: Ferruginous, anterior and posterior margins darker. Disc of pronotum somewhat darkened, broadest at posterior corners. Punctation very weak, almost evenly distributed, shiny and microsculpture absent. Sides of pronotum margined and almost evenly rounded. Angle between pronotum and elytra not pronounced, basal pronotal plicae present. Striae well defined, almost $1 / 2$ length of pronotum, strongly incurved.

Elytra: Ferruginous, with vague areas darkened (Fig. 5). Coarsely and densely punctate, shiny, microsculpture absent. Striae strongly impressed, same length as basal pronotal striae but slightly straighter.

Ventral side: Ferruginous. Prothorax and abdomen paler than other parts. Metacoxae and metaventrite covered with numerous larger punctures, surface shiny, without microreticulation. Abdominal ventrites with dense and finer punctures, shiny, microreticulation absent. Metacoxal lines almost straight, anteriorly slightly divergent. Epipleuron testaceous, with few coarse punctures, shiny, lacking microsculpture. Legs ferruginous meta-/mesotarsi set in black.

Male. Dorsal surface with coarse punctures but otherwise with shiny surface (Fig. 5). Median lobe of aedeagus as in Fig. 17A, B. Shape of median lobe fairly uniform, evenly bent in lateral view, apex straight and pointed at tip in ventral view. Parameres bi-segmented, broad and with few setae at apex (Fig. 17C, D).

Affinities. This species is very similar to $G$. chipi but readily separated by its larger size and the form of the median lobe and parameres (Figs 15, 17).

Etymology. The species is named after the type locality. The specific epithet is a substantive in the genitive case.

Distribution. Only known from the type locality Drik Drik in south-western Victoria (Fig. 22).

Habitat. The few specimens were collected in shallow water at the edge of a large, exposed but shallow farm dam, overgrown with grasses and sedges. The species is syntopic with $G$. chipi.

\section{Gibbidessus kangarooensis sp. nov.}

http://zoobank.org/9CD26871-28DA-4A6E-A9FC-DBC0F74A6DC6

Figs 6, 18, 22

Type locality. South Australia, Kangaroo Island, Eleaner River at South Coast [Road] Crossing, edge sample [35⒌' S, $\left.137^{\circ} 14^{\prime} \mathrm{E}\right]$. 
Type material. Holotype: Male, "Eleaner R. S, Coast rd AWQ [Australian Water Quality] survey 8/11/95 site 3714 [35'56'S, 137¹4'E]" "Holotype Gibbidessus kangarooensis sp. nov. Hendrich, Watts \& Balke des. 2020" [red printed label] (SAMA).

Diagnosis. Small species which externally is characterised by a more elongate body, shiny non-microreticulate dorsal surface, and with well pronounced habitus disruption between pronotum and elytron. Dorsoventrally rather flattened. Without cervical line but rather a few punctures instead (Fig. 6).

Measurements. Holotype: $\mathrm{TL}=1.55 \mathrm{~mm}, \mathrm{TL}-\mathrm{H}=1.4 \mathrm{~mm}, \mathrm{MW}=0.88 \mathrm{~mm}$.

Head: Ferruginous, without cervical line but rather a few punctures instead. Evenly and coarsely punctate, shiny, microsculpture absent. Punctures weakly anteriorly and strongly posteriorly between eyes. Antennae missing.

Pronotum: Ferruginous, anterior and posterior margins darker, broadest at middle. Punctation weak anteriorly but quite strong on posterior half and on lateral sides, almost evenly distributed, shiny and microsculpture absent. Sides of pronotum broadly margined and almost evenly rounded. Angle between pronotum and elytra well pronounced, basal pronotal and elytral plicae present. Striae moderately defined, almost $1 / 2$ length of pronotum, strongly incurved.

Elytra: Dark brown with vague basal area ferruginous (Fig. 6). Coarsely and densely punctate, shiny, microsculpture absent. Striae weakly impressed, slightly straighter and of same length as basal pronotal striae.

Ventral side: Ferruginous. Prothorax and apex of abdomen paler than other parts. Metacoxae and metaventrite covered with numerous larger punctures, surface shiny, without microreticulation. Abdominal ventrites with finer punctures, shiny, microreticulation absent. Metacoxal lines almost straight, anteriorly slightly divergent. Epipleuron ferruginous, coarsely punctate, shiny, lacking microsculpture. Legs ferruginous with meta-/mesotibia and meta-/mesotarsi somewhat darkened.

Male. Dorsal surface with coarse punctures but otherwise with shiny surface (Fig. 6). Median lobe of aedeagus as in Fig. 18A, B. Shape of median lobe, bent evenly and fairly uniform in lateral view, in ventral view pointed at apex. Parameres bi-segmented, elongated, and with few setae at apex (Fig. 18C, D).

Female. Unknown.

Affinities. This species is similar to G. pictipes but readily separated by the different colour pattern and the more flattened body. Furthermore, both species can be separated by the form of the median lobe and parameres (Figs 18, 20).

Etymology. The species is named after the type locality. The specific epithet is a substantive in the genitive case.

Distribution. A rare species, only known from the type locality on Kangaroo Island, South Australia (Fig. 22).

Habitat. The single specimen was collected at the edge of the Eleaner River in the southern part of Kangaroo Island. Most probably this is not the original habitat of the species. Almost all Gibbidessus inhabit more seasonal, open wetlands, overgrown with sedges and rushes. 


\section{Gibbidessus pederzanii sp. nov.}

http://zoobank.org/9389E4E1-D5E3-4063-A0F3-33C7FAFD045E

Figs $7,12,19,25$

Type locality. Australia, Western Australia, creek around Nannup [3358'S, 11545'E].

Type material. Holotype: Male, "Australia (WA) Nannup env. roadside creeks 1/12/98 Pederzani", "Holotype Gibbidessus pederzanii Hendrich, Watts \& Balke des. 2020" [red printed label] (SAMA). Paratypes (13 exs.): All specimens with same data as holotype. Two specimens with "SAMA Database No 25-001593" and one with a yellow printed label "photographed" (CFP, CLH, SAMA, ZSM). All paratypes are provided with printed red paratype labels.

Diagnosis. Medium-sized species which externally is characterised by a rounded habitus, without disruption between pronotum and elytron, and shiny, non-microreticulate dorsal surface with testaceous markings on elytra. Dorsoventrally rather arched. Without cervical line but rather a few punctures instead (Fig. 7).

Measurements. Holotype: TL $=1.5 \mathrm{~mm}, \mathrm{TL}-\mathrm{H}=1.3 \mathrm{~mm}, \mathrm{MW}=0.85 \mathrm{~mm}$. Paratypes: $\mathrm{TL}=1.5-1.6 \mathrm{~mm}, \mathrm{TL}-\mathrm{H}=1.3-1.4 \mathrm{~mm}, \mathrm{MW}=0.85-0.95 \mathrm{~mm}$.

Head: Ferruginous, around eyes almost black, without cervical line but rather a few punctures instead (Fig. 12B). Coarsely punctate, rather shiny, weak microreticulation visible. Punctures weakly anteriorly and strongly posteriorly between eyes. Antennae relatively short, stout. Antennomeres 1 and 2 ferruginous, 3-11 darkened anteriorly.

Pronotum: Ferruginous, anterior and posterior margins, between striae, slightly darker, broadest at posterior corners. Punctation very weak almost evenly distributed, shiny and microsculpture absent. Sides of pronotum margined and almost evenly rounded. Angle between pronotum and elytra less pronounced, basal pronotal plicae present. Striae moderately defined, almost $1 / 2$ length of pronotum, slightly incurved.

Elytra: Dark brown with vague basolateral and apical area ferruginous (Fig. 7). Coarsely and densely punctate, shiny, microsculpture absent. Striae deeply impressed, straight but shorter than basal pronotal striae.

Ventral side: Ferruginous. Prothorax and abdomen paler than other parts. Metacoxae and metaventrite covered with larger punctures, surface shiny, without microreticulation. Abdominal ventrites with dense and finer punctures, shiny, microreticulation absent. Metacoxal lines almost straight, anteriorly not divergent. Epipleuron testaceous, with few coarse punctures, shiny, lacking microsculpture. Legs ferruginous with meta- and mesotarsi somewhat darkened.

Male. Dorsal surface with coarse punctures but otherwise with shiny surface (Fig. 7). Median lobe of aedeagus as in Fig. 19A, B. Shape of median lobe, almost straight and fairly uniform in lateral view, in ventral view rounded at apex. Parameres bi-segmented, elongated, and without setae at apex (Fig. 19C, D).

Affinities. This species is similar to $G$. davidi sp. nov. but readily separated by the different colour pattern, the more roundish body (Figs 4, 7), the larger punctation on elytra, and the form of the median lobe and parameres (Figs 16, 19). 
Etymology. The species is named after our colleague, the dytiscid specialist Fernando Pederzani (Ravenna, Italy), who collected the type material. The specific epithet is a substantive in the genitive case.

Distribution. South-western Australia. A rare species, which is only known from the type locality somewhere around Nannup in south-western Australia. Most probably a more inland species and restricted to forested areas and not in heathland or coastal sedge swamps (Fig. 25).

Habitat. All specimens were collected in shallow water at the edge of a small slow flowing forest creek (F. Pederzani in litt.).

Gibbidessus pictipes (Lea, 1899), comb. nov.

Figs 8, 9, 13, 20, 30, 31

Bidessus pictipes Lea, 1899: 523 (original description).

Uvarus pictipes (Lea, 1899): Watts (1978: 33, comb. nov., redescription); Watts (1985:

24, checklist); Lawrence et al. (1987: 335, catalogue); Biström (1988: 10, systematics); Hendrich (2001a: 302, faunistics, habitat); Hendrich (2001b: 21, faunistics, habitat); Watts (2002: 31, 44, identification key, checklist); Nilsson \& Hájek (2020: 128, catalogue).

Type locality. Australia, south-western Australia, Pinjarrah [32³7'56S, 11551'49E]. Type material. Syntype, female, "pictipes Lea Type Pinjarrah" (handwritten label), "Bidessus pictipes Lea W. Australia TYPE" (handwritten label), "SAMA Database No 25-001599" (SAMA).

Additional material studied (320 exs.). 51 exs., "WA Lake Nalyerin 33 08S, 116 22E CHS, Watts 6/10/03", "SAMA Database 25-009282" (SAMA); 4 exs., "Nalyeen Lake [Nalyerin] WA J. McRae 8/10/97", "SAMA Database No 25-002918” (SAMA); 1 ex., "WA Byenup Lagoon NR 21/9/00 C.H.S. Watts" "SAMA Database No 25002922" (SAMA). 2 exs., "Australia, WA, SWA31 (A), Helena River, 22/08/2005, South-west Forest Monitoring" (DPAW); 1 ex., "Australia, WA, HAR21 (A), Stirling Dam 2, 7/09/2006, South-west Forest Monitoring" (DPAW); 3 exs., "Australia, WA, SPM011 (B) Kulicup Swamp, 6/11/1998, Salinity Action Plan Wetland Monitoring Programme" (DPAW); 1 ex., "Australia, WA, SPM011 (A) Kulicup Swamp [3420'1S, $\left.116^{\circ} 47^{\prime} 17 E\right], 23 / 10 / 2002$, Salinity Action Plan Wetland Monitoring Programme" (DPAW); 1 ex., "Australia, WA, SPM011 (B) Kulicup Swamp [34²0'1S, 116²4'17E], 23/10/2002, Salinity Action Plan Wetland Monitoring Programme" (DPAW); 2 exs., "Australia, WA, SPM011 (A) Kulicup Swamp [3420'1S, 116 47'17E], 11/10/2000, Salinity Action Plan Wetland Monitoring Programme" (DPAW); 2 exs., "Australia,

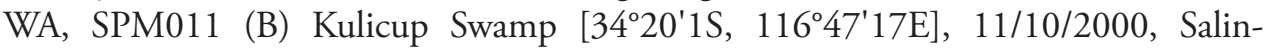
ity Action Plan Wetland Monitoring Programme" (DPAW); 1 ex., "Australia, WA,

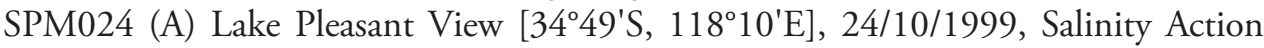




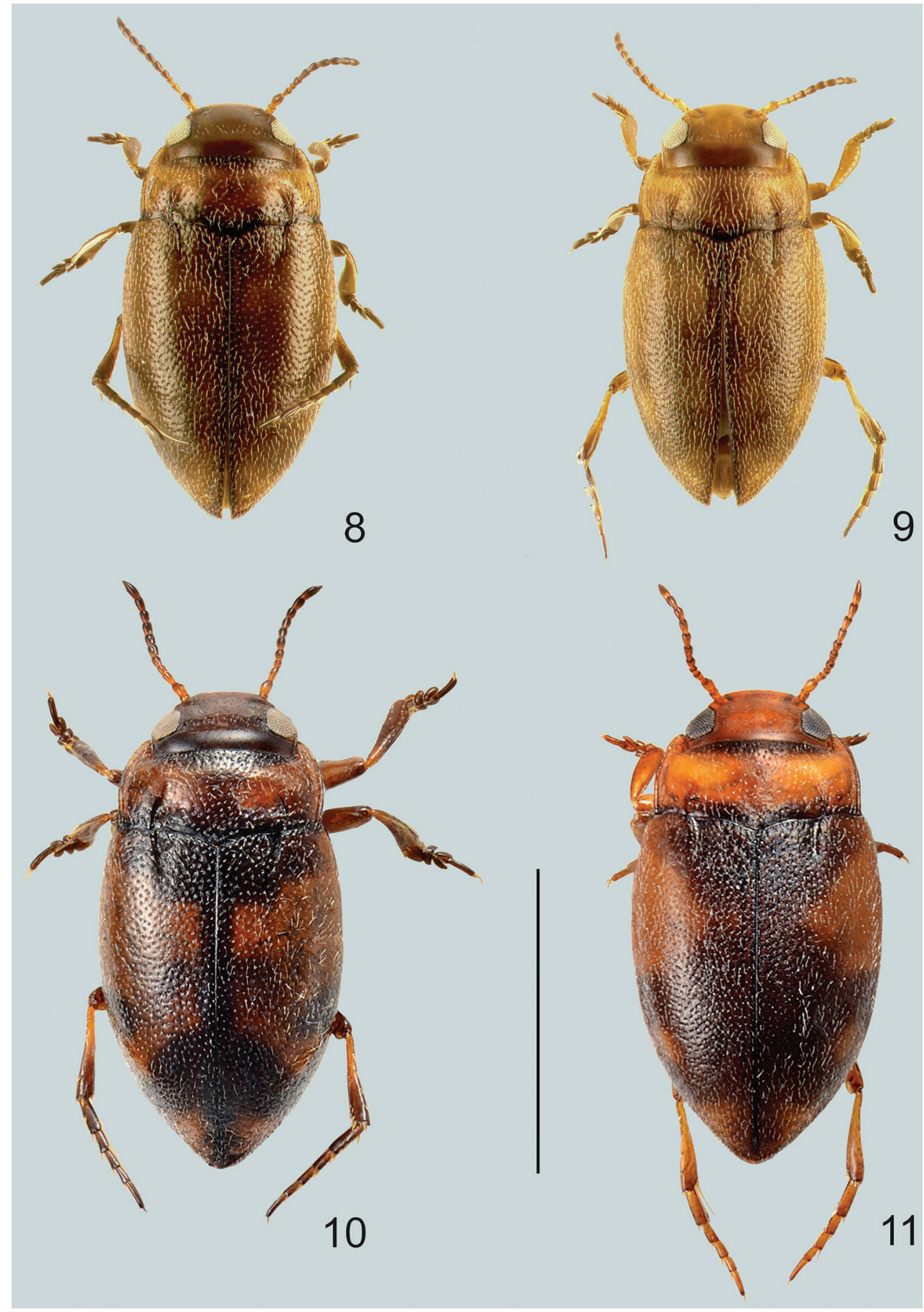

Figures 8-II. Habitus of 8 G. pictipes, male 9 G. pictipes, female 10 G. rottnestensis sp. nov., male I I G. rottnestensis sp. nov., female. Scale bar: $1.0 \mathrm{~mm}$. 

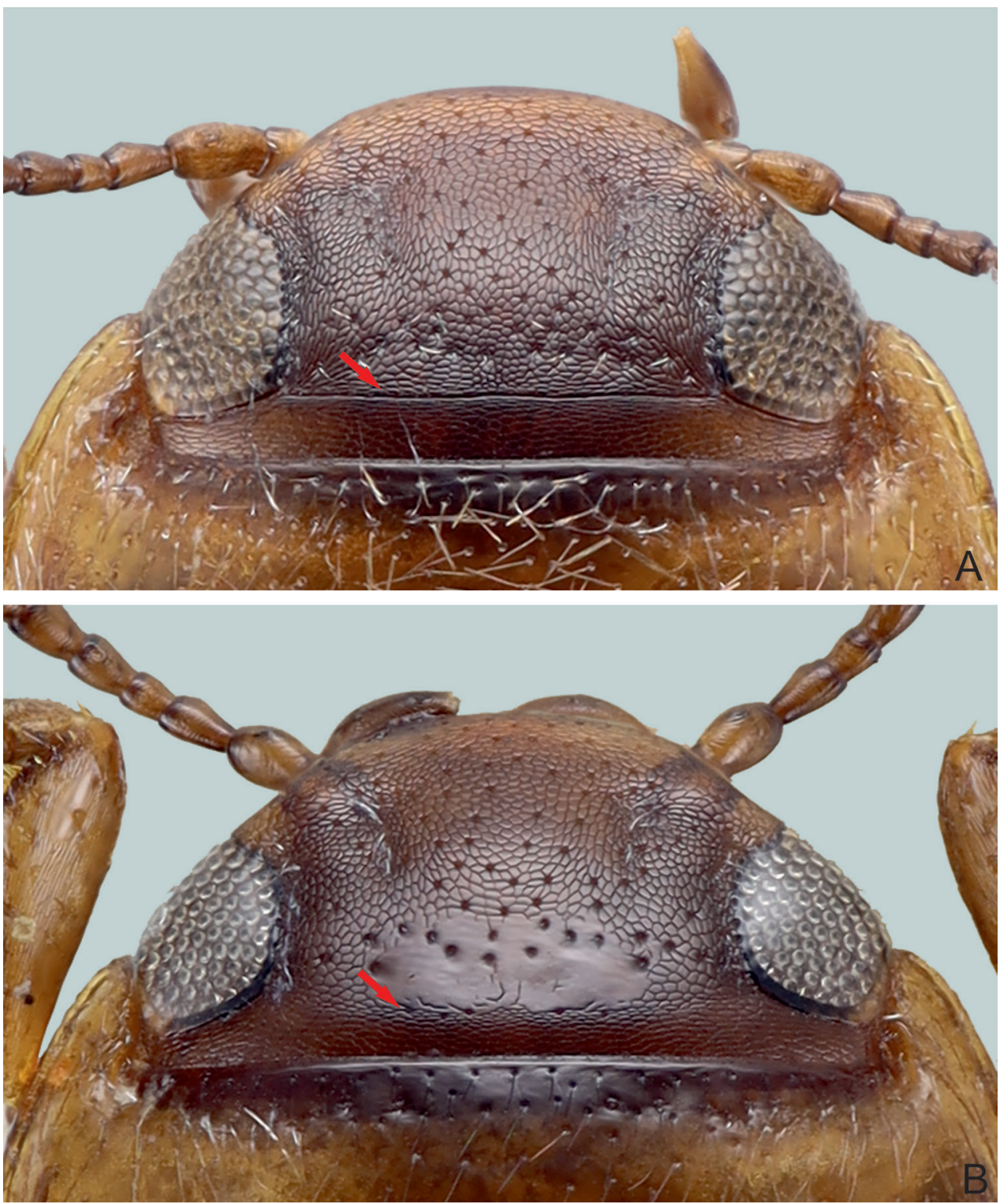

Figure 12. Head of $G$. davidi sp. nov. A with cervical line (red arrow), and head of $G$. pederzanii sp. nov. B without cervical line but rather a few punctures instead (red arrow).

Plan Wetland Monitoring Programme" (DPAW); 3 exs., "Australia, WA, SPM024 (A) Lake Pleasant View [34\% $49^{\prime}$ S, $118^{\circ} 10^{\prime} E$ ], 24/10/2003, Salinity Action Plan Wetland Monitoring Programme" (DPAW); 2 ex., "Australia, WA, SPM024 (B) Lake Pleasant View [344' S, $118^{\circ} 10^{\prime} E$ ], 24/10/2001, Salinity Action Plan Wetland Monitoring Programme" (DPAW); 4 exs., "Australia, WA, SPM024 (A) Lake Pleasant View [3449'S, $\left.118^{\circ} 10^{\prime} \mathrm{E}\right], 24 / 10 / 1999$, Salinity Action Plan Wetland Monitoring Programme" 

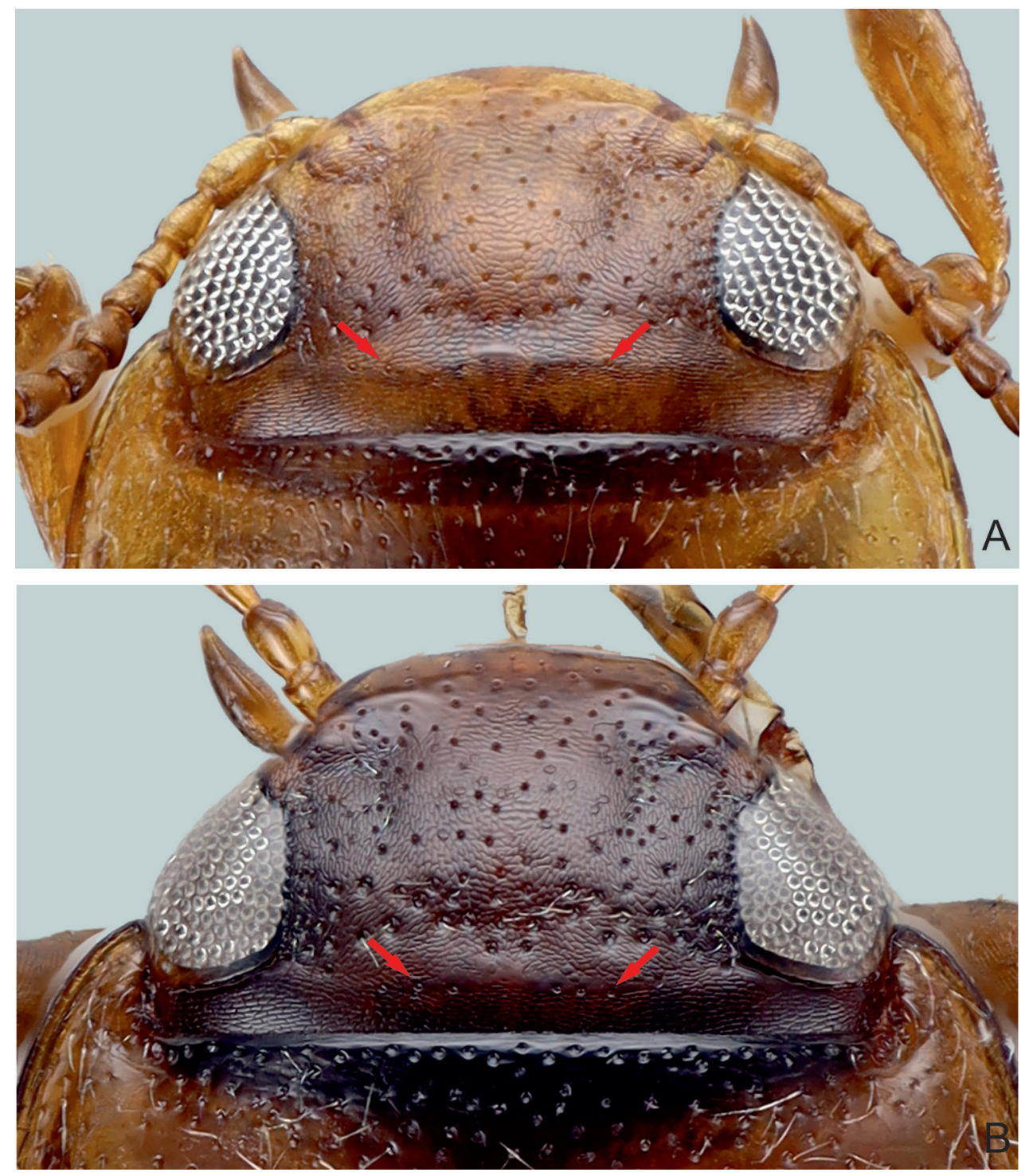

Figure 13. Head of G. pictipes A without cervical line (red arrows), and of G. rottnestensis sp. nov. B without cervical line but rather a few punctures instead (red arrows).

(DPAW); 1 ex., "Australia, WA, RUAB01 (A) Ruabon Road 01 [3337'S, 115²7'E], 11/10/2007, South-west Catchment Council Wetland monitoring" (DPAW); 1 ex., "Australia, WA, RVDLE03 (A) Riverdale 03 [3259S, 11547E], 4/10/2007, Southwest Catchment Council Wetland monitoring" (DPAW); 30 exs., "Australia, WA,

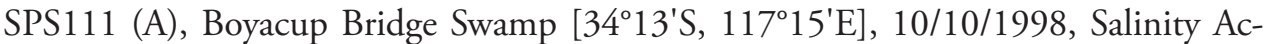
tion Plan Wetland Biological Survey" (DPAW); 1 ex., "Australia, WA, SPS032 (A), Qualeup Lake [3350'S, 116²4'E], 9/10/1998, Salinity Action Plan Wetland Biologi- 


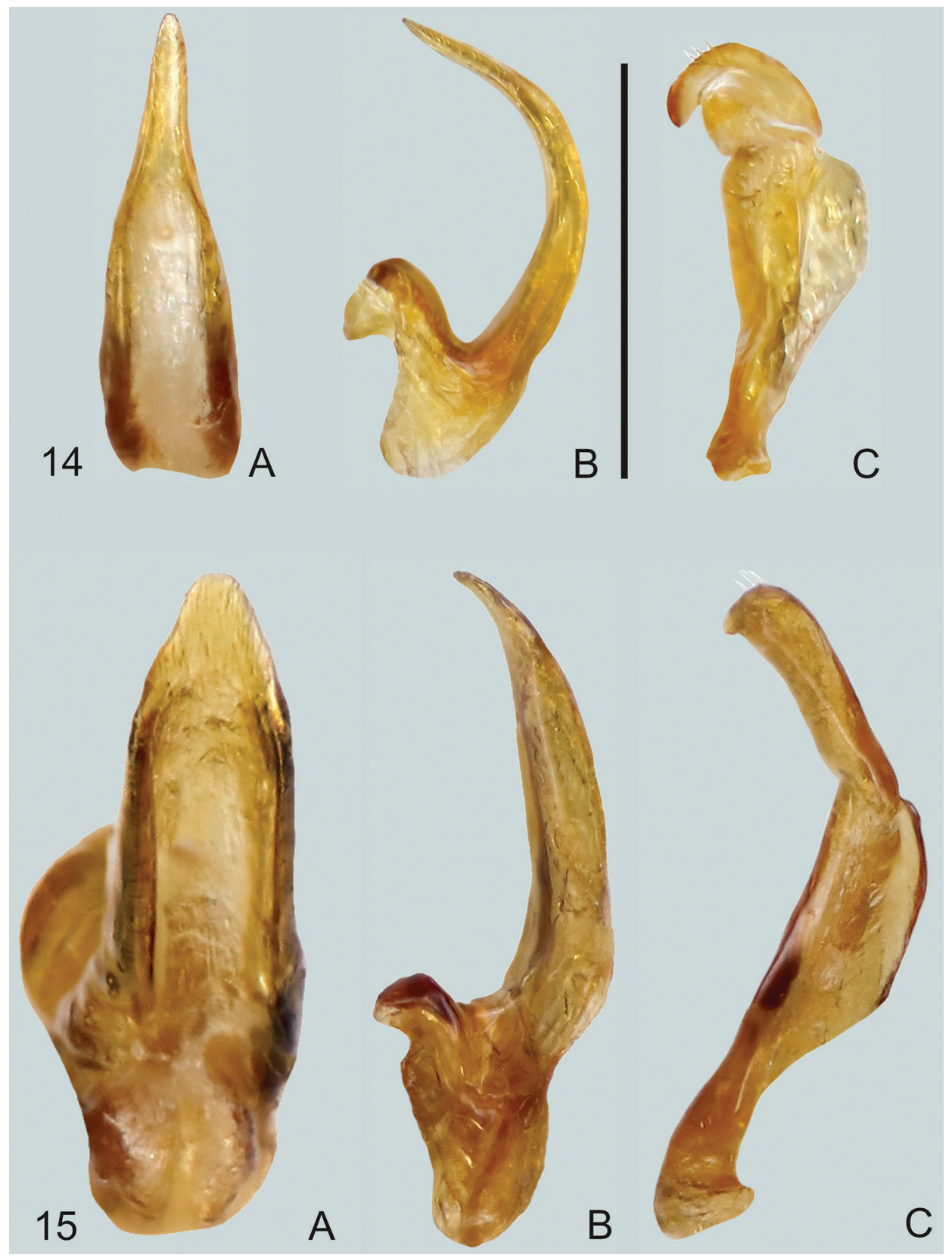

Figures I4, I5. 14 Gibbidessus atomus sp. nov. I5 G. chipi A median lobe in ventral view B median lobe in lateral view, left side $\mathbf{C}$ left paramere in lateral view. Scale bar: $0.2 \mathrm{~mm}$.

cal Survey" (DPAW); 2 exs., "Australia, WA, SPS103 (A), Lake Poorginup [34³2'S, $\left.116^{\circ} 44^{\prime} \mathrm{E}\right], 2 / 10 / 1998$, Salinity Action Plan Wetland Biological Survey" (DPAW); 4 exs., "Australia, WA, SPS104 (A), Pindicup Lake [34²5'S, 116²3'E], 2/10/1998, Sa- 


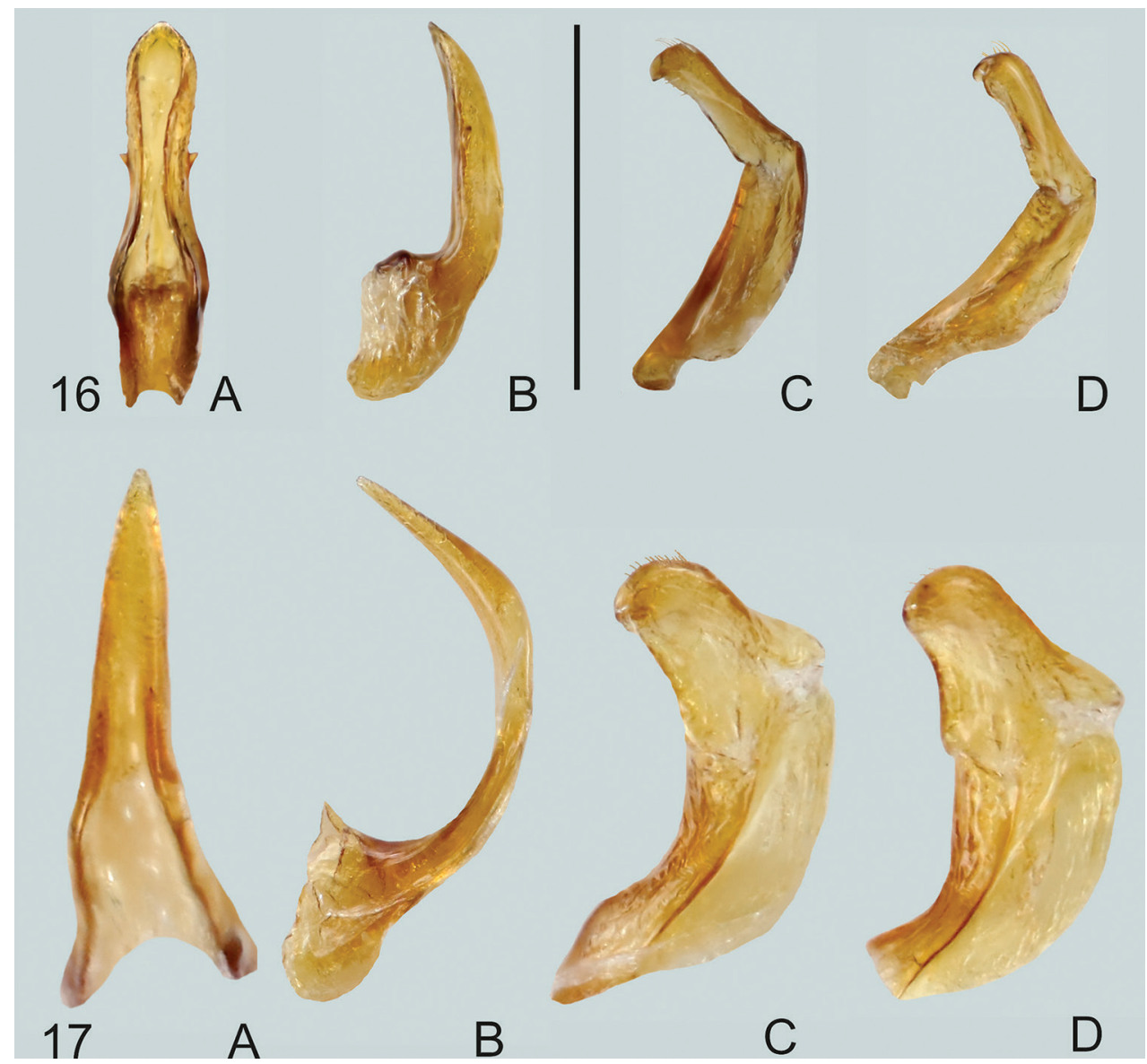

Figures 16, 17. 16 Gibbidessus davidi sp. nov. 17 G. drikdrikensis sp. nov. A median lobe in ventral view $\mathbf{B}$ median lobe in lateral view, left side $\mathbf{C}$ left paramere in lateral view, $\mathbf{D}$ right paramere in lateral view. Scale bar: $0.2 \mathrm{~mm}$.

linity Action Plan Wetland Biological Survey", one specimen "M. Balke DNA 7250" [green printed label] (DPAW, ZSM); 1 ex., "Australia, WA, MUB030 (A), Pindicup Lake [3425'S, 116 $43^{\circ} \mathrm{E}$ ], 25.09.2014, Muir-Byenup Survey" (DPAW); 11 exs., "Australia, WA, MUB030 (A), Pindicup Lake, 25.09.2014, Muir-Byenup Survey (DPAW); 4 exs., "Australia, WA, SPS105 (A) Kodjinup Melaleuca Swamp [3423'S, 116³9'E], 2/10/1998, Salinity Action Plan Wetland Biological Survey" (DPAW); 30 exs, "Australia, WA, SPS108 (A) Pillenorup Swamp, 30/09/1998, Salinity Action Plan Wetland Biological Survey" (DPAW); 7 exs., "Australia, WA, SPS113 (A) Tucker's Road Melaleuca Swamp, 27/08/1998, Salinity Action Plan Wetland Biological Survey” (DPAW); 1 ex., "Australia, WA, LVR003 (A) Lower Vasse River Site 3, 4/10/2001, Lower Vasse River Clean-up Program" (DPAW); 1 ex., "Australia, WA, LVR004 (A), Lower Vasse River Site 4, 5/10/2001, Lower Vasse River Clean-up Program" (DPAW); 1 ex., "Australia, 


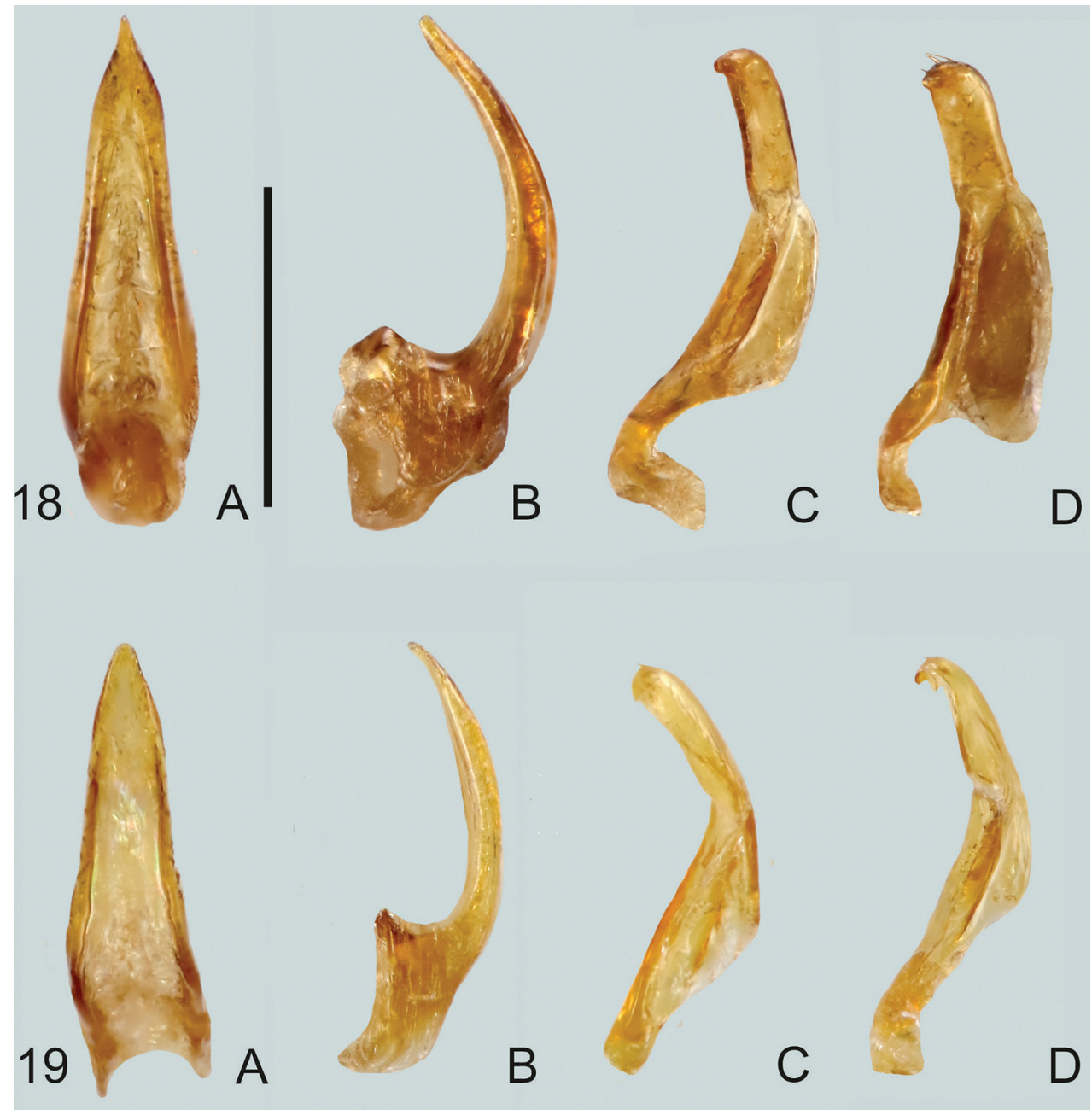

Figures 18, 19. 18 Gibbidessus kangarooensis sp. nov. 19 G. pederzanii sp. nov. A median lobe in ventral view $\mathbf{B}$ median lobe in lateral view, left side $\mathbf{C}$ left paramere in lateral view $\mathbf{D}$ right paramere in lateral view. Scale bar: $0.2 \mathrm{~mm}$.

WA, LVR005 (A), Lower Vasse River Site 5, 5/10/2001, Lower Vasse River Clean-up Program" (DPAW); 6 exs., "Australia, WA, JCS019 (A), Sedge Swamp W of Deadhorse Soak [29 $\left.54^{\circ} 7 \mathrm{~S}, 115^{\circ} 1^{\prime} 11 \mathrm{E}\right], 21 / 09 / 2011$, Jurien Coastal Survey" (DPAW); 1 ex., "Australia, WA, Mulgarnup MUB 012, 28.01.2004, Andrew Storey leg." (DPAW); 2 exs., "Australia, WA, Mulgarnup MUB 012, 1.10.2014, M. Pennifold leg.", two specimens "M. Balke DNA 7252", "M. Balke DNA 7253" [green printed labels] (ZSM); 4 exs.,

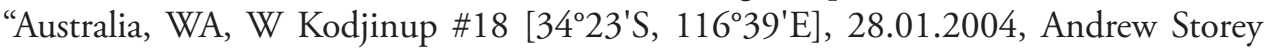

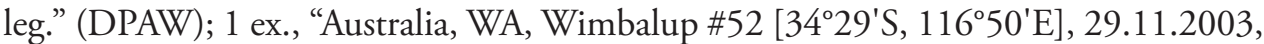
Andrew Storey leg." (DPAW); 11 exs., "Australia, WA, MUB019 (A), Galamup Swamp

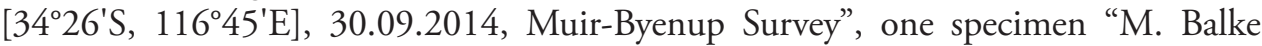




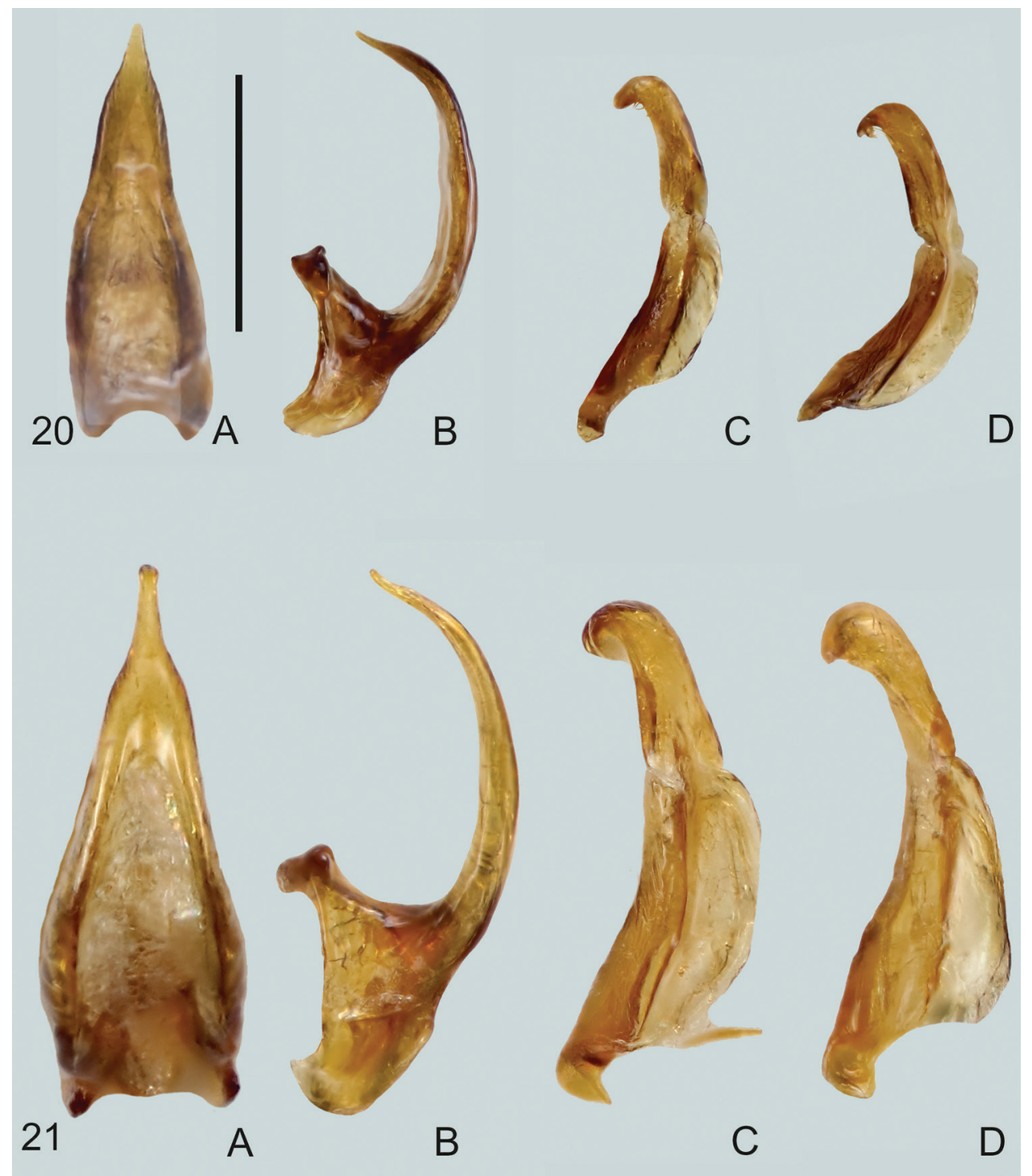

Figures 20, 2 I. 20 Gibbidessus pictipes $\mathbf{2}$ I G. rottnestensis sp. nov. A median lobe in ventral view B median lobe in lateral view, left side $\mathbf{C}$ left paramere in lateral view, $\mathbf{D}$ right paramere in lateral view. Scale bar: $0.2 \mathrm{~mm}$.

DNA 7262" [green printed label] (DPAW, ZSM); 23 exs., "Australia, WA, MUB035, NE Unicup NR [3420'S, $116^{\circ} 43^{\prime} E$ ], 24.09.2014, Muir-Byenup Survey”, one specimen "M. Balke DNA 7257" [green printed label] (DPAW, ZSM); 43 exs., "Australia, WA, MUB037 (A) S, Kulunilup NR [3420'S, 116²7'E], 25.09.2014, Muir-Byenup Survey", three specimens "M. Balke DNA 7259”, "M. Balke DNA 7260”, “M. Balke DNA 7261" [green printed labels] (DPAW, ZSM); 11 exs., "Australia, WA, 

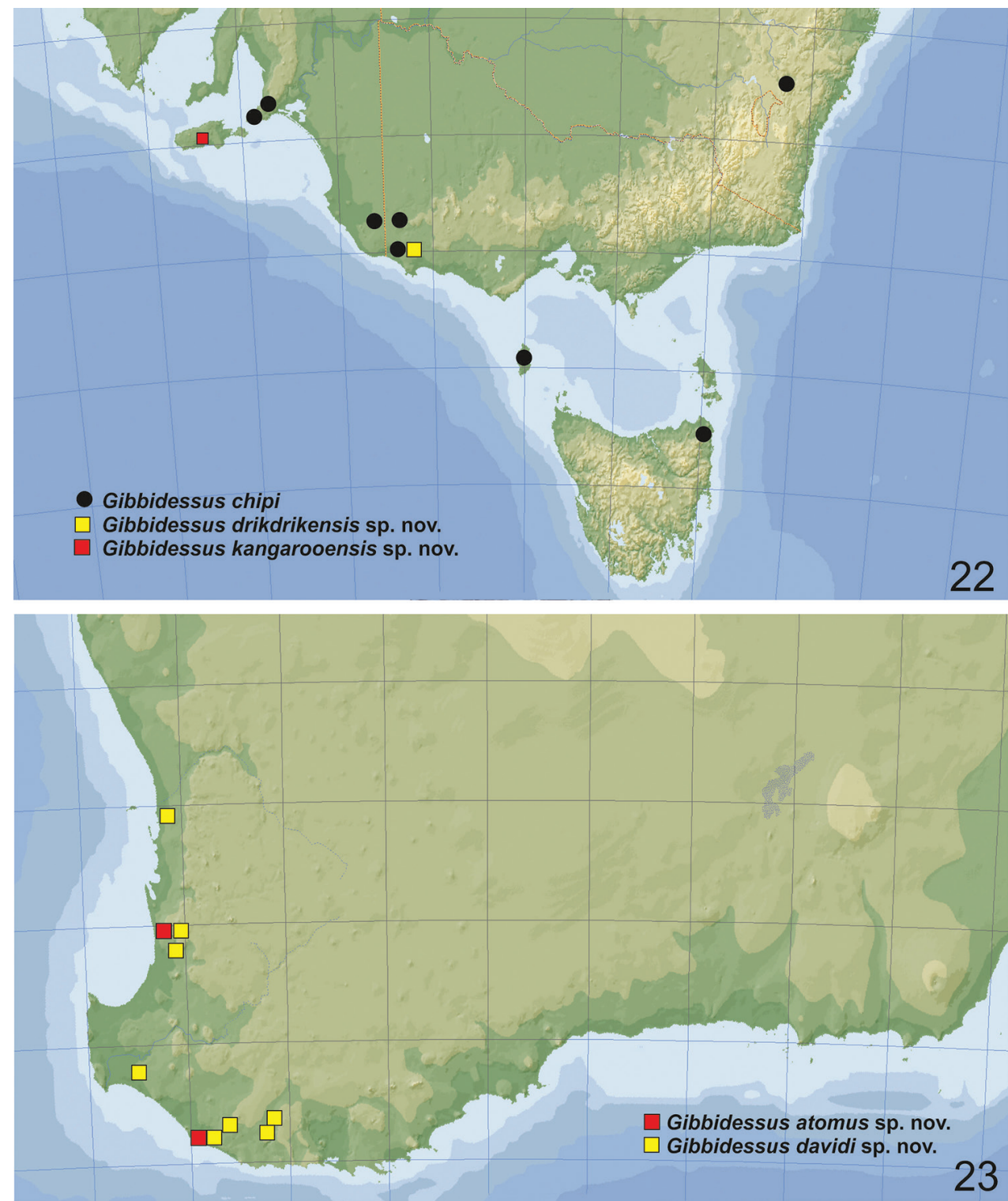

Figures 22, 23. Distribution of 22 Gibbidessus chipi (black dots), G. drikdrikensis sp. nov. (yellow square), G. kangarooensis sp. nov. (red square) 23 G. atomus sp. nov. (red square), G. davidi sp. nov. (yellow square).

MUB011 (A) Kulunilup Lake [34²0'S, 11647'E], 25.09.2014, Muir-Byenup Survey" (DPAW); 2 exs., "Australia, WA, MUB008 (B) Noobijup Swamp [34²3'S, 116 47'E], 24.09.2014, Muir-Byenup Survey" two specimens "M.Balke DNA 7254", "M. Balke DNA 7255" [green printed labels] (DPAW, ZSM); 1 ex., "Australia, WA, MUB005 (A), Yarnup Swamp [3422'26S, 116 $52^{\circ} 4 \mathrm{E}$ ], 22.09.2014, Muir-Byenup Survey” (DPAW); 12 exs., "Australia, WA, MUB012 (A), Mulgarnup Swamp [34¹5'1S, 116²1'44E], 

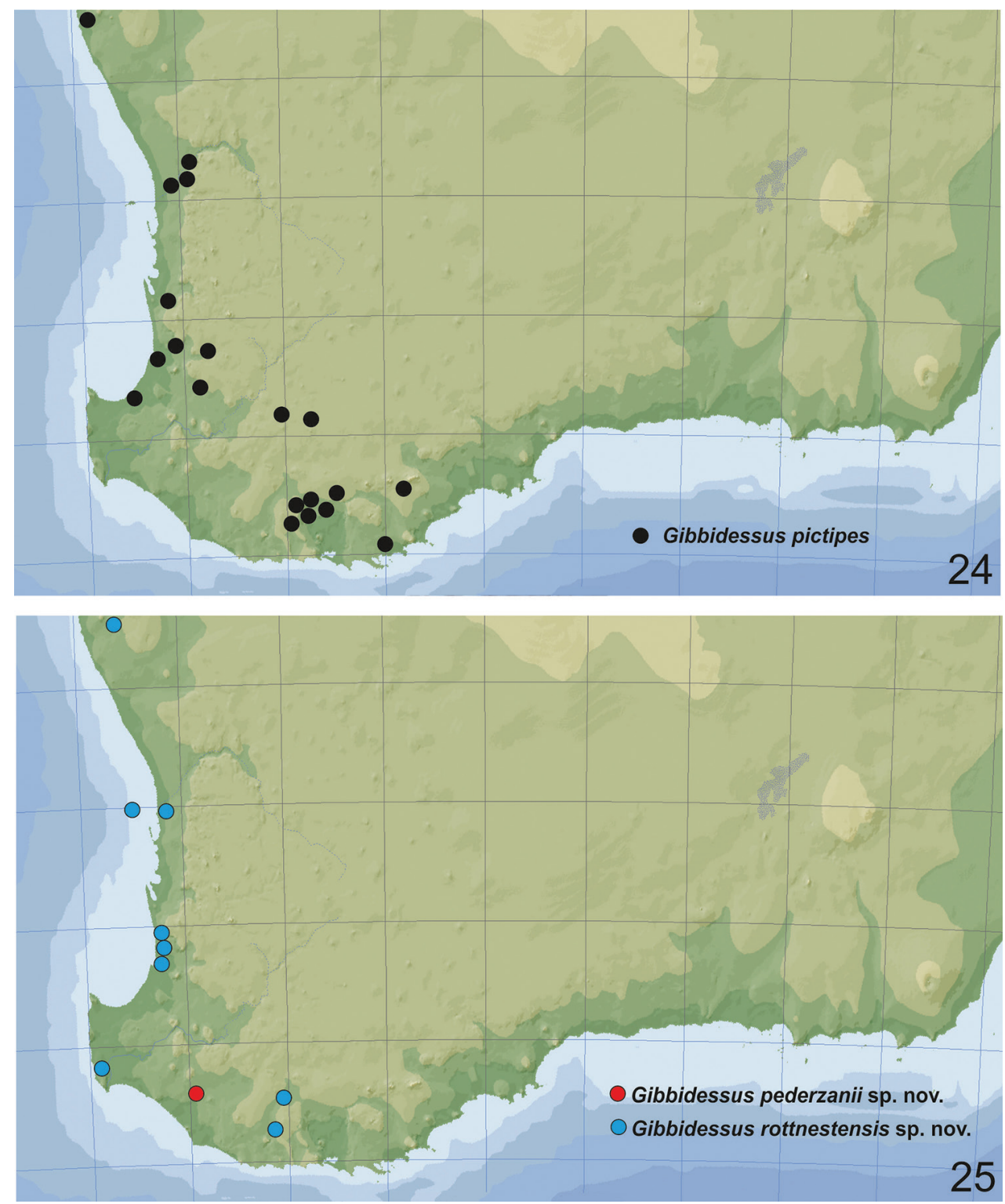

Figures 24, 25. Distribution of $\mathbf{2 4}$ Gibbidessus pictipes (black dots) 25 G. pederzanii sp. nov. (red dot), G. rottnestensis sp. nov. (blue dots).

01.10.2014, Muir-Byenup Survey" (DPAW); 1 ex., "Australia, WA, Twin Swamps NW [314'ㄱ, $116^{\circ} 0^{\prime} 50 \mathrm{E}$ ], 24/09/1992, Twin Swamps/Ellen Brook Survey” (DPAW); 1 ex., "Australia, WA, SPS031, 08/10/1997, SAP Survey" (DPAW); 1 ex., "Australia, WA, ABP041, 14/09/2007, Avon Baselining Project" (DPAW); 26 exs., "Australia, WA, Albany Hwy, Muir Lakes Nature Reserve, SW part of Byenup Lagoon, 4.\& 5.1.2000, 34²9'S, 11644'E, Hendrich leg. (loc. WA 11/157)" (CLH, ZSM); 18 ex., "Australia, 

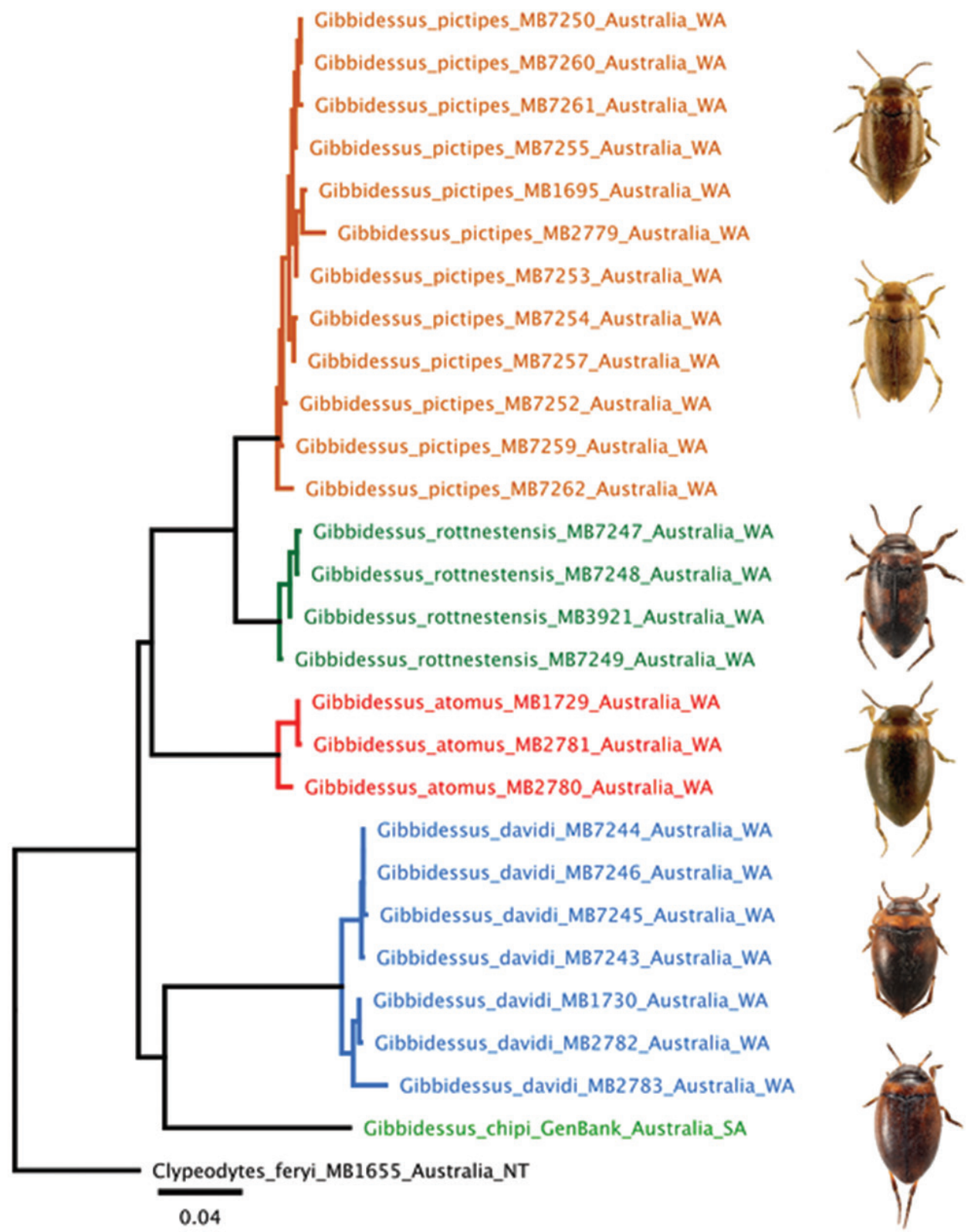

Figure 26. Maximum likelihood tree for Australian Gibbidessus. Neighbour joining tree (p-distances) calculated with Geneious (11.0.4.) software.

WA, Albany, 3 km ENE Manypeaks, Lake Pleasant Nature Reserve, 7.1.2000, 3449'S, $118^{\circ} 10^{\prime} \mathrm{E}$, Hendrich leg. (loc. WA 13/159) (CLH, ZSM); 38 exs., "Australia, WA, Darling Range, Lane Poole Conservation Reserve, Nalyerin Lake, 300 m, 29. \& 30.12.1999, 
$33^{\circ} 8.51^{\prime}$ S, $116^{\circ} 22.15^{\prime} \mathrm{E}$, Hendrich leg. (loc. WA 4/151)" (CGC, CLH, ZSM); 1 ex., "Australia: SW WA, 3 km NE Manypeaks, Lake Pleasant View NR, 91m, 2.I.2007, $34^{\circ} 49^{\prime}$ S, $118^{\circ} 10^{\prime}$ E, L. \& E. Hendrich leg. (WA 160)" (ZSM).

Note. Watts (1978), who moved Bidessus pictipes to Uvarus, already noticed that this species might not belong to Uvarus: "It is with considerable hesitation that I place the following species in this genus. I suspect that it will eventually prove to belong to a genus of its own".

Diagnosis. Small and dark brown species, with vague testaceous markings on elytra, and with habitus disruption between pronotum and elytron. Dorsoventrally rather flattened. Head without cervical line but rather a few punctures instead (punctures not obvious in females) (Fig. 8).

Measurements: Lectotype, female: $\mathrm{TL}=1.45 \mathrm{~mm}, \mathrm{TL}-\mathrm{H}=1.25 \mathrm{~mm}, \mathrm{MW}=0.82 \mathrm{~mm}$. Additional material: $\mathrm{TL}=1.45-1.6 \mathrm{~mm}, \mathrm{TL}-\mathrm{H}=1.3-1.4 \mathrm{~mm}, \mathrm{MW}=0.8-0.83 \mathrm{~mm}$.

Head: Dark brown to ferruginous, without cervical line but rather a few punctures instead (punctures not obvious in females) (Fig. 13A). Evenly and coarsely punctate, shiny but with weak microreticulation. Punctures weakly anteriorly and strongly posteriorly between eyes. Antennae relatively short, stout. Antennomeres $1-3$ ferruginous, 4-11 darkened anteriorly.

Pronotum: Ferruginous, anterior and posterior margins darker, broadest at middle. Punctation very weak, almost evenly distributed, shiny and microsculpture absent. Sides of pronotum margined and almost evenly rounded. Angle between pronotum and elytra well pronounced, basal pronotal plicae present. Striae moderately defined, almost $1 / 2$ length of pronotum, strongly incurved.

Elytra: Dark brown with vague basal area ferruginous (Fig. 8). Coarsely and densely punctate, shiny, microsculpture absent. Striae weakly impressed, slightly straighter than in female specimens and of same length as basal pronotal striae.

Ventral side: Ferruginous. Prothorax and apex of abdomen paler than other parts. Metacoxae and metaventrite covered with numerous larger punctures, surface shiny, without microreticulation. Abdominal ventrites with finer punctures, shiny, microreticulation absent. Metacoxal lines almost straight, anteriorly slightly divergent. Epipleuron ferruginous, coarsely punctate, shiny, lacking microsculpture. Legs ferruginous with meta-/mesotibia and meta-/mesotarsi somewhat darkened.

Male. Dorsal surface with coarse punctures but otherwise with shiny surface (Fig. 8). Median lobe of aedeagus as in Fig. 20A, B. Shape of median lobe, bent evenly and fairly uniform in lateral view, in ventral view tapering and pointed at apex. Parameres bi-segmented, elongated, and with setae inside apical hook (Fig. 20C, D).

Female. Dorsal surface almost mat, with coarse punctures and dense microreticulation (Fig. 9).

Affinities. This species is similar to G. kangarooensis sp. nov. and the larger $G$. rottnestensis sp. nov. ( $\mathrm{TL}=1.5-1.7 \mathrm{~mm}$ ) but readily separated by the different colour pattern. Furthermore, all three species can be separated by the form of their median lobes and parameres (Figs 18, 20, 21). 

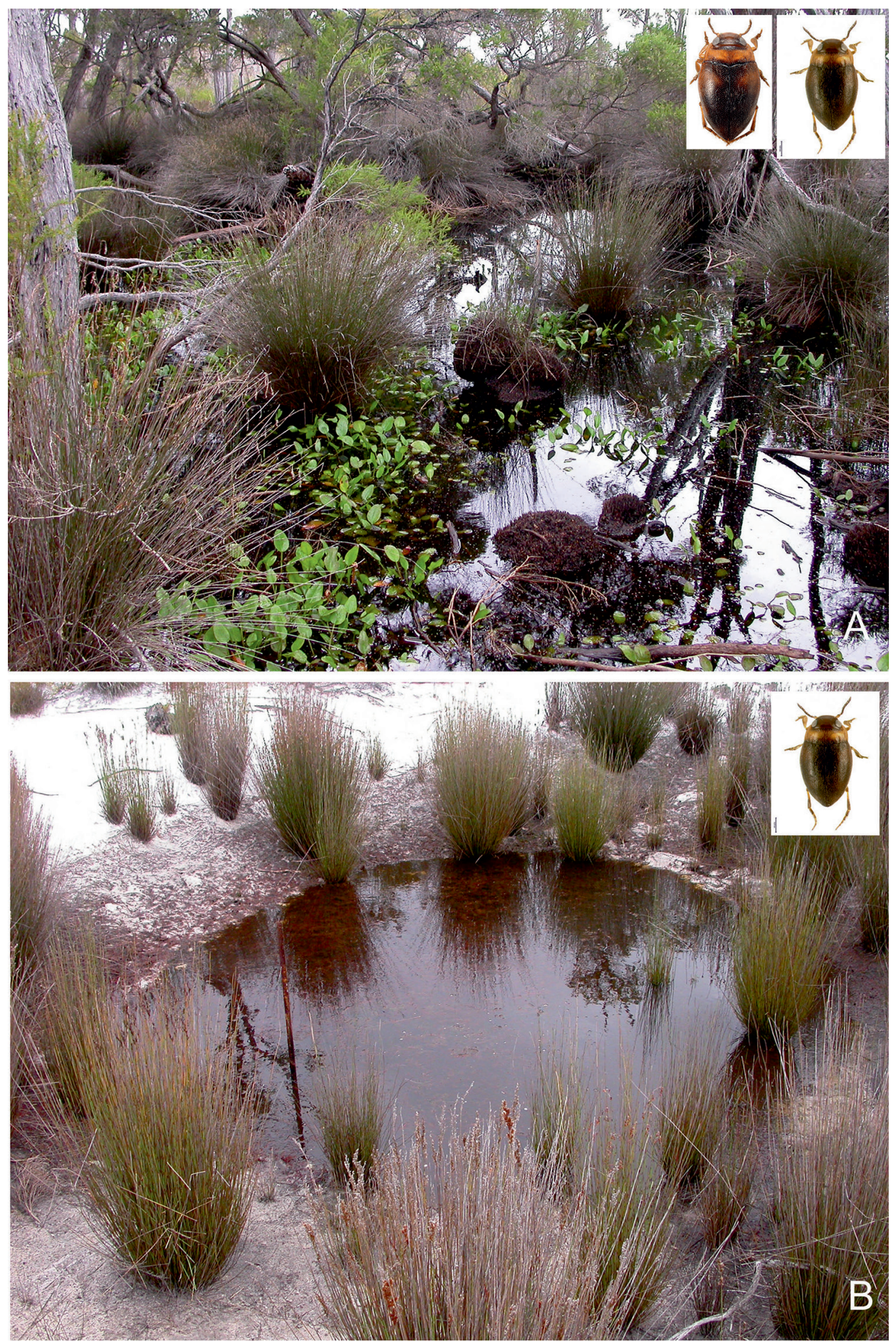

Figure 27. Habitat of Gibbidessus atomus sp. nov. and Gibbidessus davidi sp. nov. A Seasonally flooded Melaleuca sedge swamp B small and shallow heathland pool along Windy Harbour Road, south of Northcliffe, south-western Australia. 

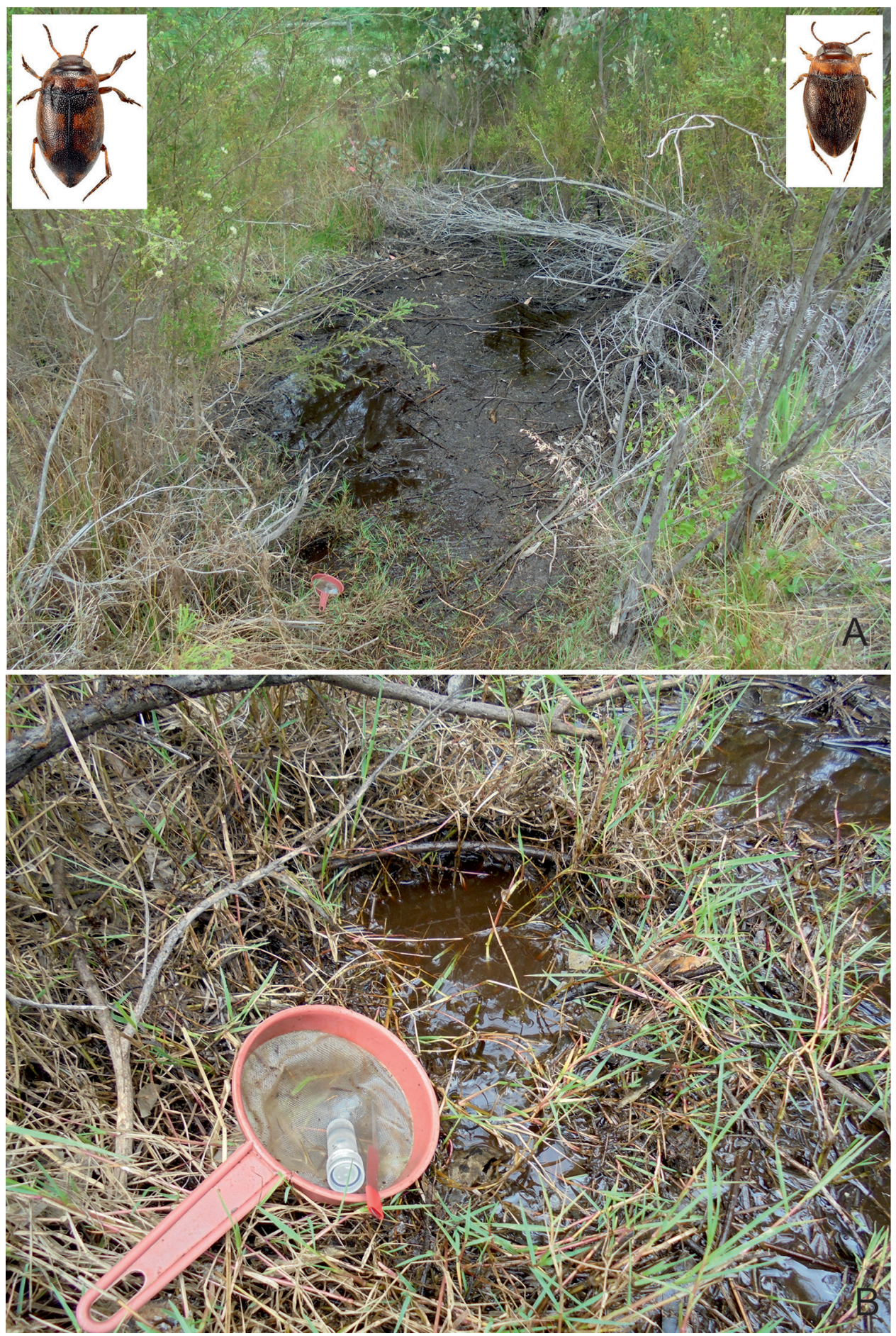

Figure 28. Habitat of Gibbidessus davidi sp. nov. and Gibbidessus rottnestensis sp. nov. A Shallow peaty pool with mats of floating grasses along Beeliar Swamps in Perth B same spot and habitat details with collecting methods. 
Distribution. South-western Australia. The most common and widespread species in south-western Australia and a more inland species. South of a line from $230 \mathrm{~km}$ north of Perth (Leeman) to Albany (Fig. 24).

Habitat. Permanent and seasonal, very shallow, sun exposed or half-shaded sedge swamps, lakeshores, larger ponds and flooded meadows on sandy bottom, with a thin layer of peat or rotten debris of sedges (Figs 30, 31). A winter and early spring breeder. Most specimens were collected in September and October, with the next generation in December and January. Apart from $G$. pictipes, the water beetle coenosis at Nalyerin Lake (Fig. 31) included the following species: Dytiscidae: Limbodessus inornatus, Antiporus hollingsworthi, Sternopriscus minimus, Exocelina ater; Hydrophilidae: Enochrus eyrensis, Limnoxenus zealandicus, Paracymus pygmaeus (see Hendrich 2001b). At Manypeaks (Fig. 30) G. pictipes was collected with the Dytiscidae: Limbodessus inornatus, Sternopriscus browni Sharp, 1882, S. multimaculatus (Clark, 1862), S. storeyi Hendrich \& Watts, 2004, S. wattsi Hendrich \& Watts, 2004, Necterosoma darwinii (Babington, 1841), Rhantus suturalis and Lancetes lanceolatus (Clark, 1863).

\section{Gibbidessus rottnestensis sp. nov.}

http://zoobank.org/C19B9505-4465-4C4B-BFD4-1BE35B7E645E

Figs 10, 11, 13, 21, 25, 28, 29

Uvarus pictipes (Lea, 1899): Watts (1978: 33, partim).

Type locality. Australia, south-western Australia, Rottnest Island [320'22S, 115³0'26E].

Type material. Holotype: Male, "W AUS, ca. $25 \mathrm{~km}$ N Augusta on Rd. 250, shallow pool, 4.11.2013, leg. Wewalka (A4)" "Holotype Gibbidessus rottnestensis Hendrich, Watts \& Balke des. 2020” [red printed label] (WAM). Paratypes (27 exs.): 4 specimens with same data as holotype (CGW, ZSM); 3 males, 1 female "Rottnest Is. [32 $2^{\circ} 22 \mathrm{~S}$, $115^{\circ} 30^{\prime 26 E}$ ] Oct' 31 W.A.”, "Australia, Harvard Exp., Darlington”, "Museum of Comparative Zoology”, "ANIC Database No. 25013255” (ANIC); 3 specimens with same data, and "SAMA Database No 25-00/596" (SAMA). 2 exs., "Australia, WA, Perth, Success, Beeliar RP, shallow peaty puddle $32^{\circ} 8^{\prime} 4 \mathrm{~S}, 115^{\circ} 50^{\prime} 22 \mathrm{E} 21 .-31.10 .2015 \mathrm{~L}$. Hendrich (WA 1/15)", “M. Balke 7248”, “M. Balke 7247” [green, printed label] (ZSM); 1 ex., "Australia, WA, Albany Hwy, Muir Lakes Nature Reserve, SW part of Byenup

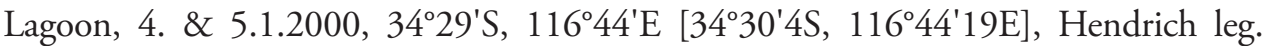
(loc. WA 11/157)" (CLH); 3 exs., "Australia, WA, $1 \mathrm{~km}$ W Kodjinup NP $34^{\circ} 24.03$ S, $116^{\circ} 38.37$ E [34²4'1S, $\left.116^{\circ} 38^{\prime} 22 \mathrm{E}\right]$ 4.X.2003, CHS, Watts leg.”, one specimen "M. Balke 3921" [green, printed label] (CLH, SAMA); 1 ex., "WA Kodjinup N.R. [3423'10S, $\left.116^{\circ} 39^{\prime} 30 E\right]$ 21/9/00 C.H.S.Watts", "SAMA Database No 25-00/594" (SAMA); 2 exs., "AUSTRALIA, WA, Midlands, 38 Km ESE Cervantes, Wongonderrah Road, Nambung River Crossing, 9.9.2002, 30³3'21S, 115²1'27E, Hendrich leg. /Loc. 28b/192b" (CLH); 1 ex., "SW Australia/ N Bunbury, Yalgorup N.P. östl. Preston Beach [3252'35S, 115\%40'6E], 0m, 24.11.1996, Hendrich leg./Lok. 30” (CLH); 1 ex., "Australia, WA, RVDLE03 Riverdale Wetland [3259'22S, 115\%47'7E], 23/09/2008, 

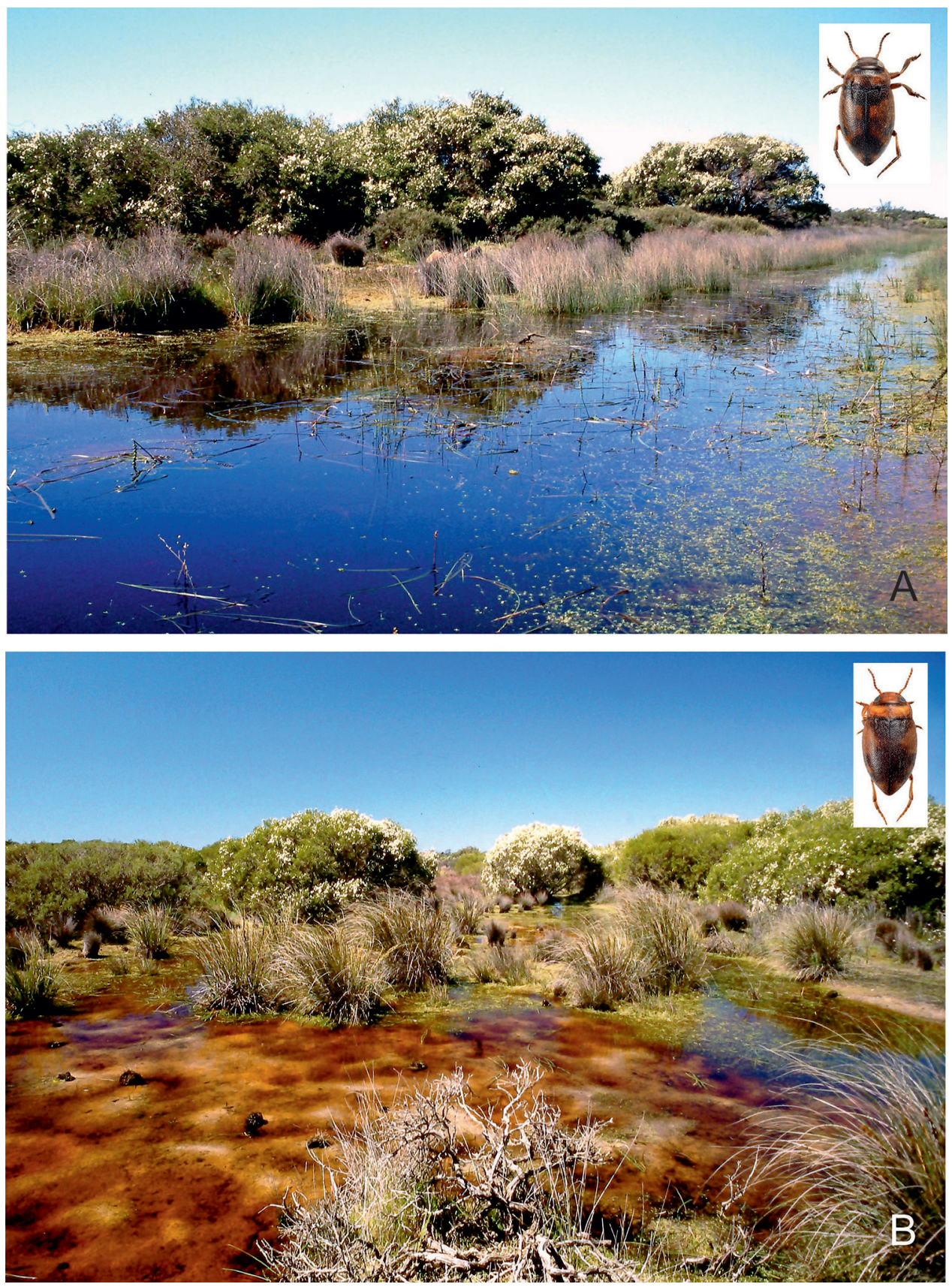

Figure 29. Habitat of Gibbidessus rottnestensis sp. nov. A and B seasonally flooded wetlands at Wongonderrah Road, Nambung River Crossing, 38 Km ESE Cervantes.

South West Catchment Council Mon." (DPAW); 1 ex., "Australia, WA, Pindicup Lake [34²4'35S, 116 43'20E], MUB030, 29.09.2014, Muir-Byenup Survey, M. Pennifold leg." (DPAW); 1 ex., “Australia, WA, Pindicup Lake [34²4'35S, 116²33'20E], MUB030, 

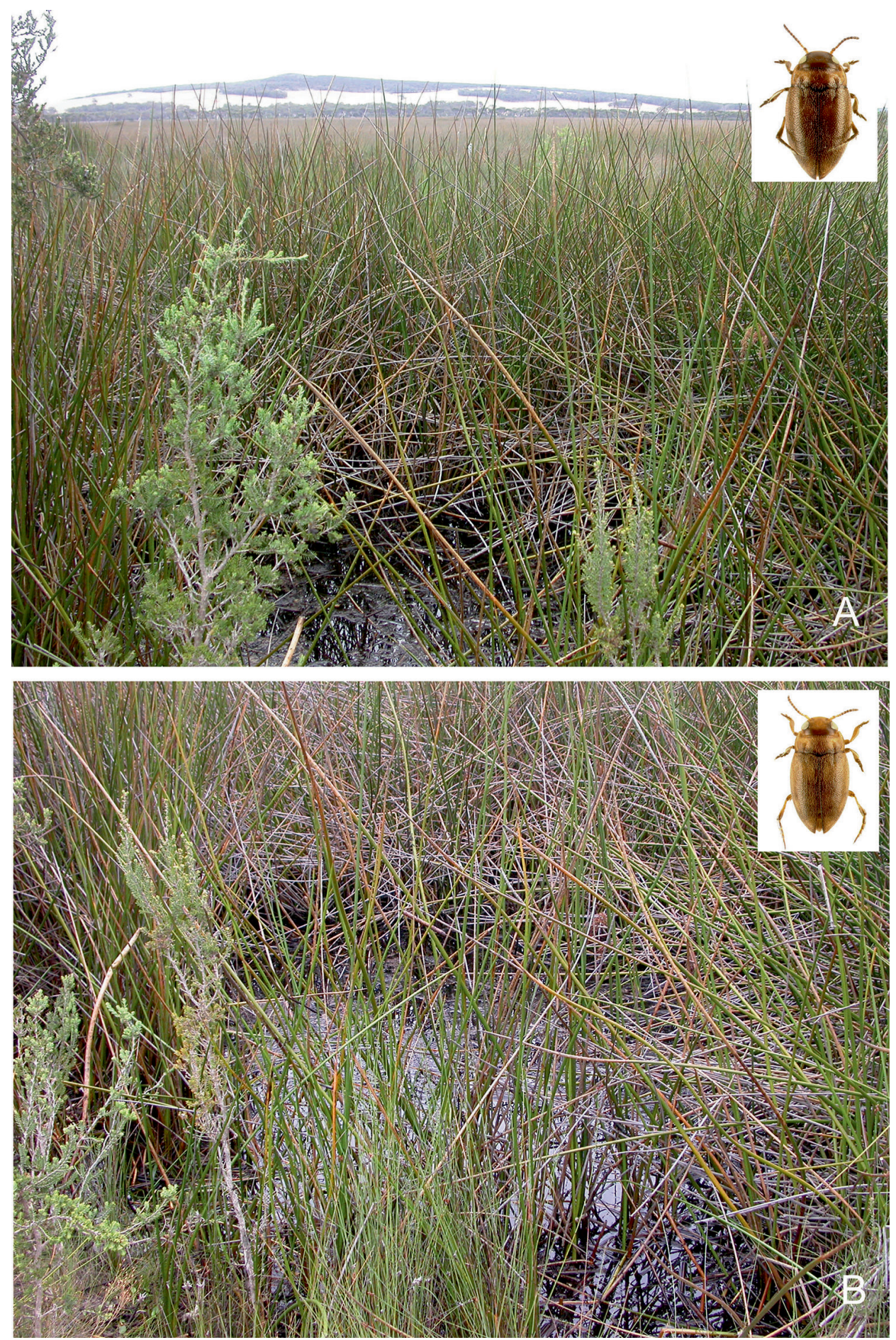

Figure 30. Habitat of Gibbidessus pictipes. A, B Seasonally flooded and exposed wetland with Baumea and sedges $3 \mathrm{~km}$ ENE Manypeaks, Lake Pleasant Nature Reserve. 

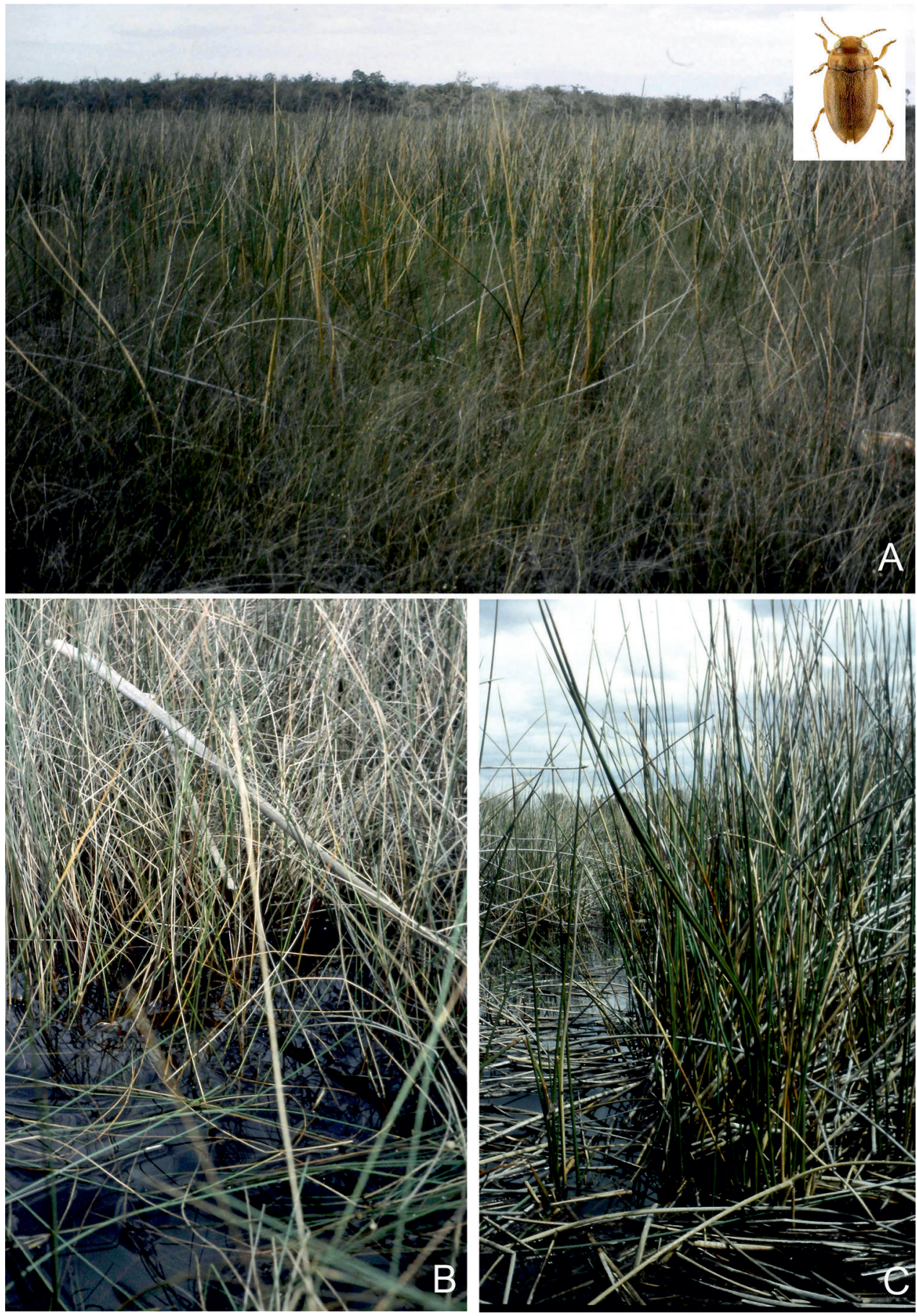

Figure 3 I. Habitat of Gibbidessus pictipes. A, B Seasonally flooded sedge swamp around lake Nalyerin $\mathbf{C}$ deeper and more permanent part of the lake, with stands of Baumea. 
25.09.2014, Muir-Byenup Survey, M. Pennifold leg." (DPAW); 2 ex., "Australia, WA,

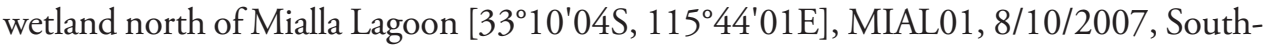
west Catchment Council Wetland Monitoring" (DPAW). All paratypes are provided with red printed paratype labels.

Note. Watts (1978: 33) reports Uvarus pictipes from Rottnest Island (housed in Museum of Comparative Zoology and SAMA); these specimens belong to Gibbidessus rottnestensis sp. nov.

Diagnosis. Larger species which externally is characterised by a more elongate body, shiny non-microreticulate dorsal surface, testaceous markings on elytra, and with distinct habitus disruption between pronotum and elytron. Dorsoventrally slightly flattened. Without cervical line but rather a few punctures instead (Fig. 10).

Measurements. Holotype: $\mathrm{TL}=1.85 \mathrm{~mm}, \mathrm{TL}-\mathrm{H}=1.65 \mathrm{~mm}, \mathrm{MW}=0.95 \mathrm{~mm}$. Paratypes: $\mathrm{TL}=1.7-1.9 \mathrm{~mm}, \mathrm{TL}-\mathrm{H}=1.5-1.7 \mathrm{~mm}, \mathrm{MW}=0.85-1.0 \mathrm{~mm}$.

Head: Black to ferruginous, without cervical line but rather a few punctures instead (punctures not obvious in females) (Fig. 13B). Evenly and coarsely punctate, shiny but with weak microreticulation. Punctures weak anteriorly and stronger posteriorly between eyes. Antennae relatively short, stout. Antennomeres 1-3 ferruginous, 4-11 darkened anteriorly.

Pronotum: Ferruginous, anterior and posterior margins darker. Broadest at middle. Punctation very strong, almost evenly distributed, shiny and microsculpture absent. Sides of pronotum broadly margined and almost evenly rounded. Angle between pronotum and elytra well pronounced, basal pronotal plicae present. Striae moderately defined, almost $1 / 2$ length of pronotum, strongly incurved.

Elytra: Dark brown to black, with distinct basal and subapical testaceous markings (Fig. 10). Coarsely and densely punctate, shiny, microsculpture absent. Striae weakly impressed, slightly incurved and of same length as basal pronotal striae.

Ventral side: Ferruginous. Prothorax and apex of abdomen paler than other parts. Metacoxae and metaventrite covered with numerous larger punctures, surface shiny, without microreticulation. Abdominal ventrites with finer punctures, shiny, microreticulation absent. Metacoxal lines almost straight, anteriorly slightly divergent. Epipleuron ferruginous, coarsely punctate, shiny, lacking microsculpture. Legs ferruginous with meta-/mesotibia and meta-/mesotarsae somewhat darkened.

Male. Dorsal surface with coarse punctures but otherwise with shiny surface (Fig. 10). Median lobe of aedeagus as in Fig. 21A, B. Shape of median lobe, bent evenly and fairly uniform in lateral view, in ventral view strongly tapering and rounded at apex. Parameres bi-segmented, elongated, without setae inside apical hook (Fig. 21C, D).

Female. Dorsal surface almost mat, with coarse punctures and dense microreticulation (Fig. 11).

Affinities. This species is similar to the smaller $G$. pictipes $(\mathrm{TL}=1.45-1.6 \mathrm{~mm})$ but readily separated by the different colour pattern on elytra. Furthermore, both species can be separated by the form of their median lobes and parameres (Figs 20, 21).

Etymology. The species is named after the type locality. The specific epithet is a substantive in the genitive case. 
Distribution. South-western Australia. Widespread but always rare and in low population densities. A more coastal species, from around $100 \mathrm{~km}$ north of Perth to south of Augusta and eastwards to the Muir Lakes (Fig. 25).

Habitat. Seasonal, very shallow and exposed sedge swamps, pool and puddles on sandy bottom, with a thin layer of peat and rotten debris of sedges (Figs 28, 29). Gibbidessus rottnestensis sp. nov. tolerates slightly saline water as it was found at Preston Beach in a shallow lagoon near the coast. According to the data it is an early spring breeder. Most specimens were collected in September and October. In the Riverdale Wetland the species was syntopic with Gibbidessus atomus sp. nov. and G. davidi sp. nov. For the rich water beetle coenosis in Beeliar Regional Park near Perth see under Gibbidessus davidisp. nov. In the seasonal swamps at Wongonderrah Road, near Nambung River Crossing, the species was collected with several hundred specimens of an undescribed Exocelina species and Hyderodes crassus Sharp, 1882; at Preston Beach north of Bunbury it was collected with Hyphydrus elegans (Montrouzier, 1860), Necterosoma darwinii, and Platynectes aenescens Sharp, 1882.

\section{Key to Gibbidessus Watts, 1978}

1 Head with cervical line (Fig. 12A). Body roundish and without habitus disruption between pronotum and elytron. Dorsoventrally rather domed ....... 2 Head without cervical line (Figs 12B, 13). Body roundish or elongate, with or without habitus disruption between pronotum and elytron. Dorsoventrally domed or flattened....................................................................

2 Species distributed in south-eastern Australia....................................... 3

- Species distributed in south-western Australia ........................................4

3 Smaller, TL $=1.5-1.55 \mathrm{~mm}$. Median lobe and paramere as in Fig. 15. South Australia, Victoria, New South Wales, Tasmania ................................chipi

- $\quad$ Larger, TL $=1.6-1.7 \mathrm{~mm}$. Median lobe and parameres as in Fig.17. Victoria..... drikdrikensis sp. nov.

4 Smaller, $\mathrm{TL}=1.15-1.3 \mathrm{~mm}$. Median lobe and paramere as in Fig. 12. From Perth area south to Northcliffe.

atomus sp. nov.

- $\quad$ Larger, TL $=1.35-1.5 \mathrm{~mm}$. Median lobe and parameres as in Fig. 16. From Perth area south to Northcliffe. davidi sp. nov.

5 Species distributed in south-eastern Australia. Body elongate, with pronounced habitus disruption between pronotum and elytron. Dorsoventrally rather flattened, $\mathrm{TL}=1.55 \mathrm{~mm}$. Median lobe and parameres as in Fig. 18. Kangaroo Island, South Australia kangarooensis sp. nov. Species distributed in south-western Australia

Body elongate, with pronounced habitus disruption between pronotum and elytron.

- Body roundish and without habitus disruption between pronotum and elytron. Dorsoventrally rather domed, with more widely separated punctation on elytra. TL $=1.5-1.6 \mathrm{~mm}$. Median lobe and parameres as in Fig. 19. Nannup and Pemberton area 
$7 \quad$ Elytron dark brown without distinct testaceous basal marking (Figs 8, 9). Smaller, $\mathrm{TL}=1.45-1.6 \mathrm{~mm}$. Median lobe and parameres as in Fig. 20. Occurs more inland, south of a line from Perth to Albany pictipes comb. nov. - Elytron with a broad testaceous basal marking (Figs 10, 11). Larger, TL = 1.7-1.9 mm. Median lobe and parameres as in Fig. 21. A more coastal species, from around $100 \mathrm{~km}$ north of Perth to south of Augusta and eastward to the Muir Lakes. rottnestensis sp. nov.

\section{Discussion}

South-western Australia has long been recognised as a hotspot of aquatic macroinvertebrate and microfaunal diversity (Horwitz 1997; Segers and Shiel 2003). Four of the six described species of Gibbidessus are elements of this endemic freshwater fauna, and constitute a significant qualitative contribution to the biodiversity of the region. Three species are distributed in the southeast, including one endemic species from Kangaroo Island. Most probably more intensive studies will reveal further species occurring along the lowland coastal areas of south-western and south-eastern Australia.

Seven species of the genus are strictly lentic, appearing to be restricted to shallow and temporary pools, puddles, flooded meadows and seasonal sedge swamps in peatland areas or to very shallow waters at the edges of peaty lakes. One species, G. pederzanii sp. nov. was collected only at the edge of a shallow and slow-flowing forest creek. Occasionally, single specimens of G. pictipes and G. chipi have been found in slowly flowing or intermittent creeks. All species can be found in spring and early summer, and the majority of specimens have been collected between September and October. In the southern and more humid parts of south-western Australia, specimens of the new generation can be collected from November until January. Within any of their habitats, up to three species of the genus can be found (e.g., Riverdale Wetland); aggregations of several hundred specimens of at least one species are possible (e.g., Beeliar Regional Park in Perth and Lake Nalyerin). According to our experience, the occurrence of any Gibbidessus species indicates a high conservation value of the sampled water body or wetland.

The larvae of all species are still undescribed. The adults of all species seem to be capable of flight, but no specimens of any species have been obtained by operating light traps.

\section{Acknowledgements}

We are indebted to Gilbert L. Challet (Florida, USA), Fernando Pederzani (Ravenna, Italy). Melita Pennifold and Adrian Pinder (Department of Parks and Wildlife, Perth, Australia) for lending valuable specimens, and to Alexander Riedel (Karlsruhe, Germany) and František Slamka (Bratislava, Slovakia) for some excellent habitus photos. Hans Fery (Berlin, Germany) is thanked for critically reading a first draft of the manu- 
script. The Department of Conservation and Land Management is acknowledged for giving permission to conduct scientific research in Nature Reserves [Permit numbers: SF 003017 and NE 002348], and the Department of Sustainability and Environment in Victoria [Research Permit No. 10003840] is acknowledged for giving permission to conduct scientific research in National and State Parks. This work was supported by grants from Deutsche Forschungsgemeinschaft DFG (BA 2152/4-1, 6-1 and 7-1; HE 5729/1-1), as well as from the CLIMAQUA project funded by the Bundesministerium für Bildung und Forschung (BMBF) (grant \# 01DR14001 to M. Balke). Lars Hendrich warmly thanks Emma Hendrich (Munich, Germany), Stephan Gottwald and Ingo Weckwerth (both Berlin, Germany) for their patience, assistance, and enthusiastic encouragement during several field trips.

\section{References}

Balke M, Ribera I (2004) Jumping across Wallace's line: Allodessus and Limbodessus revisited (Coleoptera: Dytiscidae, Bidessini) based on molecular-phylogenetic and morphological data. Australian Journal of Entomology 43: 114-128. https://doi.org/10.1111/j.14406055.2004.00415.x

Balke M, Warikar E, Toussaint EFA, Hendrich L (2013) Papuadessus baueri sp. nov. from Biak Island, Papua (Coleoptera: Dytiscidae: Hydroporinae). Spixiana 36(2): 283-288.

Balke M, Ruthensteiner B, Warikar E, Neven K, Hendrich L (2015) Two new species of Limbodessus diving beetles from New Guinea - short verbal descriptions flanked by online content (digital photography, $\mu \mathrm{CT}$ scans, drawings and DNA sequence data). Biodiversity Data Journal 3: e7096. https://doi.org/10.3897/BDJ.3.e7096

Biström O (1988) Generic review of the Bidessini (Coleoptera, Dytiscidae). Acta Zoologica Fennica 184: 1-41.

Davies PE, Brown K, Walker R, Cook L (2003) The aquatic fauna of King Island's streams and wetlands. In: Donaghey R (Ed.) The Fauna of King Island. A Guide to Identification and Conservation Management. Natural Heritage Trust, Australia, 152 pp.

Hendrich L (2001a) A new species of Antiporus Sharp, 1882 from peatland swamps of southwestern Australia (Coleoptera: Dytiscidae). Linzer biologische Beiträge 33(1): 299-308.

Hendrich L (2001b) A new species of Hygrobia Latreille, from peatlands of south-western Australia (Coleoptera: Hygrobiidae). Koleopterologische Rundschau 71: 17-25.

Hendrich L, Balke M (2009) Kakadudessus tomweiri, a new genus and species of diving beetle from tropical northern Australia, based on molecular phylogenetic and morphological data (Coleoptera, Dytiscidae, Bidessini). Zootaxa 2134: 49-59. https://doi.org/10.11646/ zootaxa.2134.1.4

Hendrich L, Wang LJ (2006) Taxonomic revision of Australian Clypeodytes (Coleoptera: Dytiscidae, Bidessini). Entomological Problems 37(2): 1-11.

Hendrich L, Pons J, Ribera I, Balke M (2010) Mitochondrial Cox1 Sequence Data Reliably Uncover Patterns of Insect Diversity but Suffer from High Lineage-Idiosyncratic Error Rates. PloS ONE 5(12): e14448. https://doi.org/10.1371/journal.pone.0014448 
Hendrich L, Lemann C, Weir TA (2019) 11. Dytiscidae LEACH, 1815. In: Slipinski A, Lawrence J (Eds) Australian Beetles, Volume 2 - Archostemata, Myxophaga, Adephaga, Polyphaga (part). CSIRO Publishing, 34-60.

Horwitz P (1997) Comparative endemism and richness of the aquatic invertebrate fauna in peatlands and shrublands of far south-western Australia. Memoirs of the Museum of Victoria 56(2): 313-321. https://doi.org/10.24199/j.mmv.1997.56.19

Lawrence JF, Weir TA, Pyke JE (1987) Haliplidae, Hygrobiidae, Noteridae, Dytiscidae and Gyrinidae. In: Walton DW (Ed.) Zoological Catalogue of Australia. 4. Coleoptera: Archostemata, Myxophaga and Adephaga edited by the Bureau of Flora and Fauna. Canberra: Australian Government Publishing Service, 444 pp.

Lea AM (1899) Descriptions of new species of Australian Coleoptera. Part V. Proceedings of the Linnean Society of New South Wales 23: 512-645.

Miller KB, Nilsson AN (2003) Homology and terminology: Communicating information about rotated structures in water beetles. Latissimus 17: 1-4.

Miller KB, Short AEZ (2015) Belladessus Miller \& Short (Coleoptera: Dytiscidae: Hydroporinae: Bidessini), new genus for two new species from northern South America: Parthenogenetic diving beetles? The Coleopterists Bulletin 69: 498-503. https://doi.org/10.1649/0010065X-69.3.498

Nilsson AN, Hájek J (2020) A World Catalogue of the Family Dytiscidae, or the Diving Beetles (Coleoptera, Adephaga). Version 1.I.2020. Distributed as a PDF file via Internet. http:// www.waterbeetles.eu [accessed 08 February 2020]

Segers H, Shiel RJ (2003) Microfaunal Diversity in a Biodiversity Hotspot: New Rotifers from Southwestern Australia. Zoological Studies 42(4): 516-521.

Watts CHS (1978) A revision of the Australian Dytiscidae (Coleoptera). Australian Journal of Zoology Supplement Series 57: 1-166. https://doi.org/10.1071/AJZS057

Watts CHS, (1985) A faunal assessment of Australian Hydradephaga. Proceedings of the Academy of Natural Sciences of Philadelphia 137(1): 22-28.

Watts CHS, (2002) Checklist and guides to the identification, to genus, of adults and larval Australian water beetles of the families Dytiscidae, Noteridae, Hygrobiidae, Haliplidae, Gyrinidae, Hydraenidae and the superfamily Hydrophiloidea (Insecta - Coleoptera). Cooperative Research Centre for Freshwater Ecology (Australia). Identification and Ecology Guide 43: 1-110.

Watts CHS, Humphreys WF (2001) A new genus and six new species of Dytiscidae (Coleoptera) from underground waters in the Yilgarn palaeodrainage system of Western Australia. Records of the South Australian Museum 34(2): 99-114.

Watts, CHS, Humphreys WF (2003) Twenty-five new Dytiscidae (Coleoptera) of the genera Tjirtudessus Watts \& Humphreys, Nirripirti Watts \& Humphreys and Bidessodes Régimbart from underground waters in Australia. Records of the South Australian Museum 36(2): 135-187.

Watts CHS, Humphreys WF (2004) Thirteen new Dytiscidae (Coleoptera) of the genera Boongurrus Larson, Tjirtudessus Watts \& Humphreys and Nirripirti Watts \& Humphreys, from underground waters in Australia. Transactions of the Royal Society of South Australia 128(2): 99-129. 
Watts CHS, Humphreys WF (2006) Twenty-six new Dytiscidae (Coleoptera) of the genera Limbodessus Guignot and Nirripirti Watts \& Humphreys, from underground waters in Australia. Transactions of the Royal Society of South Australia 130(1): 123-185. https:// doi.org/10.1080/3721426.2006.10887055

Watts CHS, Humphreys WF (2009) Fourteen new Dytiscidae (Coleoptera) of the genera Limbodessus Guignot, Paroster Sharp, and Exocelina Broun from underground waters in Australia. Transactions of the Royal Society of South Australia 133(1): 62-107. https://doi.or g/10.1080/03721426.2009.10887112

Watts CHS, Leys R (2005) Review of the epigean species of Australian Limbodessus Guignot (Insecta: Coleoptera: Dytiscidae). Transactions of the Royal Society of South Australia 129: 1-13. 